Research article

urn:1sid:zoobank.org:pub:B8FED1DD-D057-49AE-A013-12F67F8C69B9

\title{
A new species of Pseudopaludicola (Anura, Leptodactylidae, Leiuperinae) from the state of Minas Gerais, Brazil
}

\author{
Felipe Silva de ANDRADE ${ }^{1, *}$, Isabelle Aquemi HAGA², Mariana Lúcio LYRA³, \\ Thiago Ribeiro de CARVALHO ${ }^{4}$, Célio Fernando Baptista HADDAD 5 , \\ Ariovaldo Antonio GIARETTA ${ }^{6} \&$ Luís Felipe TOLEDO ${ }^{7}$
}

\footnotetext{
${ }^{1,7}$ Laboratório de História Natural de Anfíbios Brasileiros (LaHNAB), Departamento de Biologia Animal, Instituto de Biologia, Universidade Estadual de Campinas (UNICAMP), Campinas, São Paulo, Brasil

${ }^{1,2,6}$ Laboratório de Taxonomia e Sistemática de Anuros Neotropicais (LTSAN), Instituto de Ciências Exatas e Naturais do Pontal (ICENP), Universidade Federal de Uberlândia (UFU), Ituiutaba, Minas Gerais, Brasil

${ }^{1}$ Programa de Pós-Graduação em Biologia Animal, Instituto de Biologia, Universidade Estadual de Campinas (UNICAMP), Campinas, São Paulo, Brasil ${ }^{3,4,5}$ Universidade Estadual Paulista (UNESP), Departamento de Zoologia e Centro de Aquicultura (CAUNESP), Instituto de Biociências, Rio Claro, São Paulo, Brasil

* Corresponding author: felipe_andrade@ymail.com

${ }^{2}$ Email: hagaisabelle@gmail.com

33Email: marillyra@gmail.com

${ }^{4}$ Email: thiago_decarvalho@yahoo.com.br

5Email: haddad1000@gmail.com

${ }^{6}$ Email: aagiaretta@gmail.com

${ }^{7}$ Email: toledosapo@gmail.com
}

\footnotetext{
${ }^{1}$ urn:1sid:zoobank.org:author:A6B5147E-158C-459C-97A7-B4E7ADE3DB23

${ }^{2}$ urn:1sid:zoobank.org:author:10EA92D6-7C2E-4141-A912-6E45B4EDF321

${ }^{3}$ urn:lsid:zoobank.org:author:7AD8365F-7BD9-4C37-9C41-8A0F03766E7C

${ }^{4}$ urn:lsid:zoobank.org:author:A1286A8F-C01A-421B-8135-A333D321AC95

${ }^{5}$ urn:1sid:zoobank.org:author:DCB4C25F-987D-402C-855B-E9CDDD7CDD08

${ }^{6}$ urn:Isid:zoobank.org:author:3A195123-AD86-42EC-8D18-756EC8BA6AB0

${ }^{7}$ urn:1sid:zoobank.org:author:2430A30A-DB39-4C75-9508-F9489557A223
}

\begin{abstract}
The genus of Neotropical frogs Pseudopaludicola Miranda-Ribeiro, 1926 includes 23 species, which occur throughout South America. Herein we describe a new species of Pseudopaludicola from the central region of the state of Minas Gerais (southeastern Brazil). This new species is distinguished by the adult morphology, the advertisement call, and molecular data. It is diagnosed mainly by its small size, terminal phalanges knobbed (lack of any expansion of the digital tips), proportionally short hind limbs, and its advertisement call composed of series of two-pulsed notes, emitted at a high repetition rate. In addition, we report the occurrence of the new species in the southern foothills of the Serra do Cipó National Park, at elevations lower than $800 \mathrm{~m}$ above sea level (a.s.l). The sister species of this new
\end{abstract}


taxon is P. mineira Lobo, 1994, which occurs in rupestrian grasslands above $1200 \mathrm{~m}$ a.s.l. at the Serra do Cipó National Park and in Serra do Cabral, both in the state of Minas Gerais, Brazil. We also redescribe the advertisement call of $P$. mineira based on recordings from topotypical males and compare it to calls of related species.

Keywords. Advertisement call, integrative taxonomy, Pseudopaludicola matuta sp. nov., Pseudopaludicola mineira, Serra do Cipó National Park.

Andrade F.S., Haga I.A., Lyra M.L., Carvalho T.R., Haddad C.F.B., Giaretta A.A. \& Toledo L.F. 2018. A new species of Pseudopaludicola (Anura, Leptodactylidae, Leiuperinae) from the state of Minas Gerais, Brazil. European Journal of Taxonomy 480: 1-25. https://doi.org/10.5852/ejt.2018.480

\section{Introduction}

The monophyletic genus Pseudopaludicola Miranda-Ribeiro, 1926 comprises 23 species (Frost 2018) that occur throughout South America, east of the Andes (Lynch 1989). Lynch (1989) proposed the P. pusilla group that includes nowadays five species: P. boliviana Parker, 1927, P. ceratophyes Rivero \& Serna, 1985, P. llanera Lynch, 1989, P. pusilla (Ruthven, 1916) and P. motorzinho Pansonato, VeigaMenoncello, Mudrek, Jansen, Recco-Pimentel, Martins \& Strüssmann, 2016, all sharing T-shaped terminal phalanges. Lobo (1995), Veiga-Menoncello et al. (2014) and Andrade et al. (2016, 2018), based on phylogenetic analyses, recovered Pseudopaludicola and the P. pusilla group as clades. Toledo (2010) proposed the $P$. saltica group, which contains currently three species, sharing the synapomorphy of relatively long hind limbs: P. saltica (Cope, 1887), P. murundu Toledo, Siqueira, Duarte, VeigaMenoncello, Recco-Pimentel \& Haddad, 2010, and P. jaredi Andrade, Magalhães, Nunes-de-Almeida, Veiga-Menoncello, Santana, Garda, Loebmann, Recco-Pimentel, Giaretta \& Toledo, 2016. This group was later corroborated by the phylogenetic analysis of Veiga-Menoncello et al. (2014). In the last eight years 12 Brazilian species of the genus Pseudopaludicola were described, suggesting that species diversity within this genus is still incompletely understood (Toledo et al. 2010; Pansonato et al. 2012, 2014, 2016; Carvalho 2012; Andrade \& Carvalho 2013; Roberto et al. 2013; Magalhães et al. 2014; Andrade et al. 2016, 2018; Cardozo et al. 2018).

Pseudopaludicola mineira Lobo, 1994 is a species known only from the type locality, in the Campo Rupestre (rupestrian grasslands) of the Serra do Cipó National Park, the southern portion of the Espinhaço mountain range, and in Serra do Cabral, municipality of Buenópolis, both in the state of Minas Gerais, southeastern Brazil (Lobo 1994). The advertisement call of this species was described based on two males from its type locality (Pereira \& Nascimento 2004). Pereira \& Nascimento (2004) compared $P$. mineira acoustically to P. falcipes (Hensel, 1867), P. mystacalis (Cope, 1887), P. saltica, and P. facureae Andrade \& Carvalho, 2013 (referred as $P$. aff. saltica). Veiga-Menoncello et al. (2014) and Andrade et al. $(2016,2018)$ were unable to completely resolve the phylogenetic relationships of $P$. mineira within the clade with species that presented the karyotype number of $2 n=22$.

Regional sympatry or even syntopic occurrence of two or more species of Pseudopaludicola has been reported in the literature (e.g., Giaretta \& Facure 2009; Pansonato et al. 2013). Carvalho (2012) briefly reported the existence of a population of Pseudopaludicola sp. (P. aff. mineira) that occurs in syntopy with P. giarettai Carvalho, 2012 at its type locality (municipality of Curvelo, Minas Gerais, Brazil). In addition, we found a second population of the same species in the southern foothills of the Serra do Cipó National Park, Minas Gerais, Brazil. We, therefore, evaluated it based on morphological, bioacoustic, and genetic data in order to assess its taxonomic status, which revealed this to be an undescribed species. Thus, we describe it as a new taxon, sister to $P$. mineira. In order to strengthen the diagnosis of the new species, we also provide novel acoustic data for topotypical males of $P$. mineira. 


\section{Material and Methods}

\section{Reference specimens}

Examined individuals of the new species were collected under permit \#62146-1 issued by SISBio/ Instituto Chico Mendes de Conservação da Biodiversidade. Accordingly to current legislation, the access to the National System for the Management of Genetic Heritage and Associated Traditional Knowledge was registered (SISGen \#A2FCFCC). Individuals were killed by applying 5\% lidocaine to their skin. We collected muscle tissue for genetic analyses. After that, we fixed specimens in $10 \%$ formalin and transferred them to $70 \%$ ethanol for permanent storage. Type specimens are deposited in the amphibian collection of the Museu de Zoologia "Adão José Cardoso" (ZUEC) at the Universidade Estadual de Campinas (Unicamp), Campinas, state of São Paulo, and in the collection of frogs of the Museu de Biodiversidade do Cerrado (AAG-UFU) at the Universidade Federal de Uberlândia (UFU), Uberlândia, state of Minas Gerais, both in Brazil. The new species hypothesis follows to the General Lineage Concept, which treats species as separately evolving metapopulation lineages (de Queiroz 1998, 2007).

\section{Morphometric analyses}

We measured 16 adult males and five adult females of the new species from the municipality of Curvelo, Minas Gerais, Brazil. We measured three adult males and three adult females of the new species from the southern foothills of the Serra do Cipó National Park (lowland area, $797 \mathrm{~m}$ a.s.1.), municipality of Santana do Riacho, Minas Gerais, Brazil (Fig. 1). For comparison with its most closely related species, we measured all four types (MZUSP 56858-61) and 18 topotypes of P. mineira designated by Lobo (1994) (MZUSP 56768-72, 56867, 57719-23, 57725-7, 57729-30). In addition, we measured additional 20 topotypes of P. mineira from the highlands of the Serra do Cipó National Park. Further details on examined specimens are given in Appendix I.

We measured specimens under a stereomicroscope Zeiss Stemi DV4 coupled to an ocular micrometer; except SVL, which was measured with a Mitutoyo Absolute digital caliper (to the nearest $0.1 \mathrm{~mm}$ ) under a stereomicroscope. Twelve morphometric traits were measured following Watters et al. (2016): snoutvent length (SVL), head length (HL), head width (HW), eye diameter (ED), interorbital distance (IOD), eye-nostril distance (END), snout length (SL), internarial distance (IND), hand length (HAL), thigh length (TL), tibia length (TBL), and foot length (FL). Tarsus length (TAL) was measured following Heyer et al. (1990). Shape of the snout in dorsal and lateral views follows Heyer et al. (1990).

\section{Bioacoustics}

We recorded calls with two digital recorders at a sampling rate of $44.1 \mathrm{kHz}$ and a sample size of 16 bits: Marantz PMD 661MKII (Marantz, Japan) and M-audio Microtrack II (M-audio, USA), both with Sennheiser ME66/K6 directional microphone (Sennheiser electronic GmbH \& Co. KG, Germany). Directional microphones were positioned about $1.5 \mathrm{~m}$ from the calling male. We analysed calls with Raven Pro v. 1.5, 64-bit version (Bioacoustics Research Program 2014) with the following settings: window type $=$ Hann; window size $=256$ samples; $3 \mathrm{~dB}$ filter bandwidth $=248 \mathrm{~Hz}$; brightness $=50 \%$; contrast $=50 \%$; overlap $=85 \%$ (locked); DFT size $=1024$ samples $($ locked); grid spacing $($ spectral resolution) $=43.1 \mathrm{~Hz}$. Temporal traits were measured on oscillograms and spectral traits were measured on spectrograms. Raven obtained the peaks of dominant frequency through the "Peak Frequency (Hz)" function; the frequency values with 5 and $95 \%$ of call energy were obtained by "Frequency $5 \%$ " and "Frequency 95\%" functions; and were considered as the minimum and maximum frequencies (Hz), respectively. 
Call duration was considered the total time that males spent emitting the series of two-pulsed notes. Pulse rate was quantified as the number of pulses of a note divided by the duration of this same note. We generated call figures using the Seewave v.1.6 package (Sueur et al. 2008) in R version 3.4.1 64-bit (R Core Team 2017). Seewave settings were: Hanning window, 90\% overlap, and 512 points resolution (FFT). Pulse terminology follows Magalhães et al. (2014), and overall acoustic terminology follows Köhler et al. (2017). We calculated means and standard deviations of the new species considering mean values of all individual males, whereas the range presented (variation) encompasses the minimum and maximum values for all call samples. For each advertisement call, we analysed 20 notes and all pulse/ interpulse intervals that comprise these notes. We also assessed the within-male call variation through the coefficients of variation $[\mathrm{CV}=(\mathrm{SD} /$ mean $) \times 100]$. We considered only the stereotyped two-pulsed
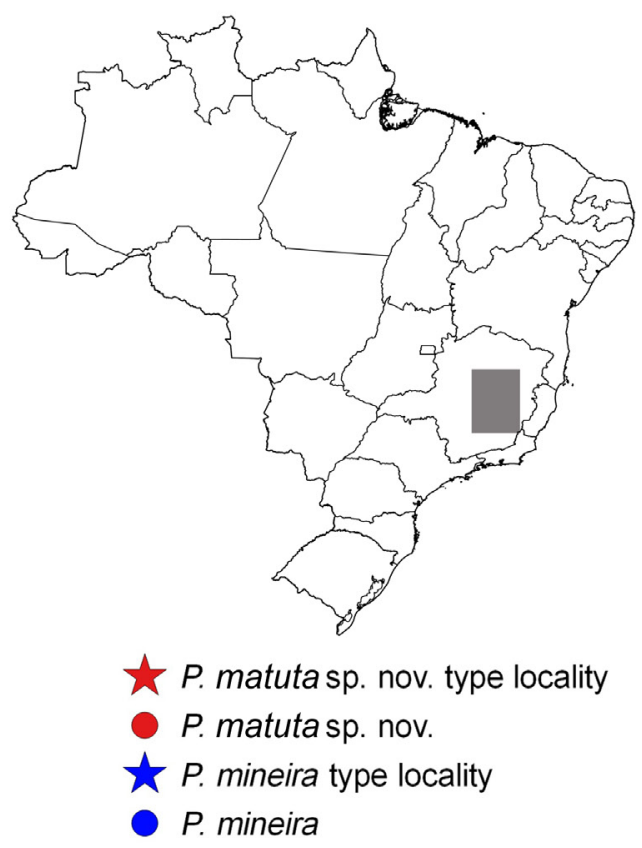

\section{Elevation $(m)$}

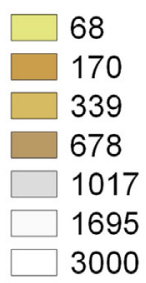

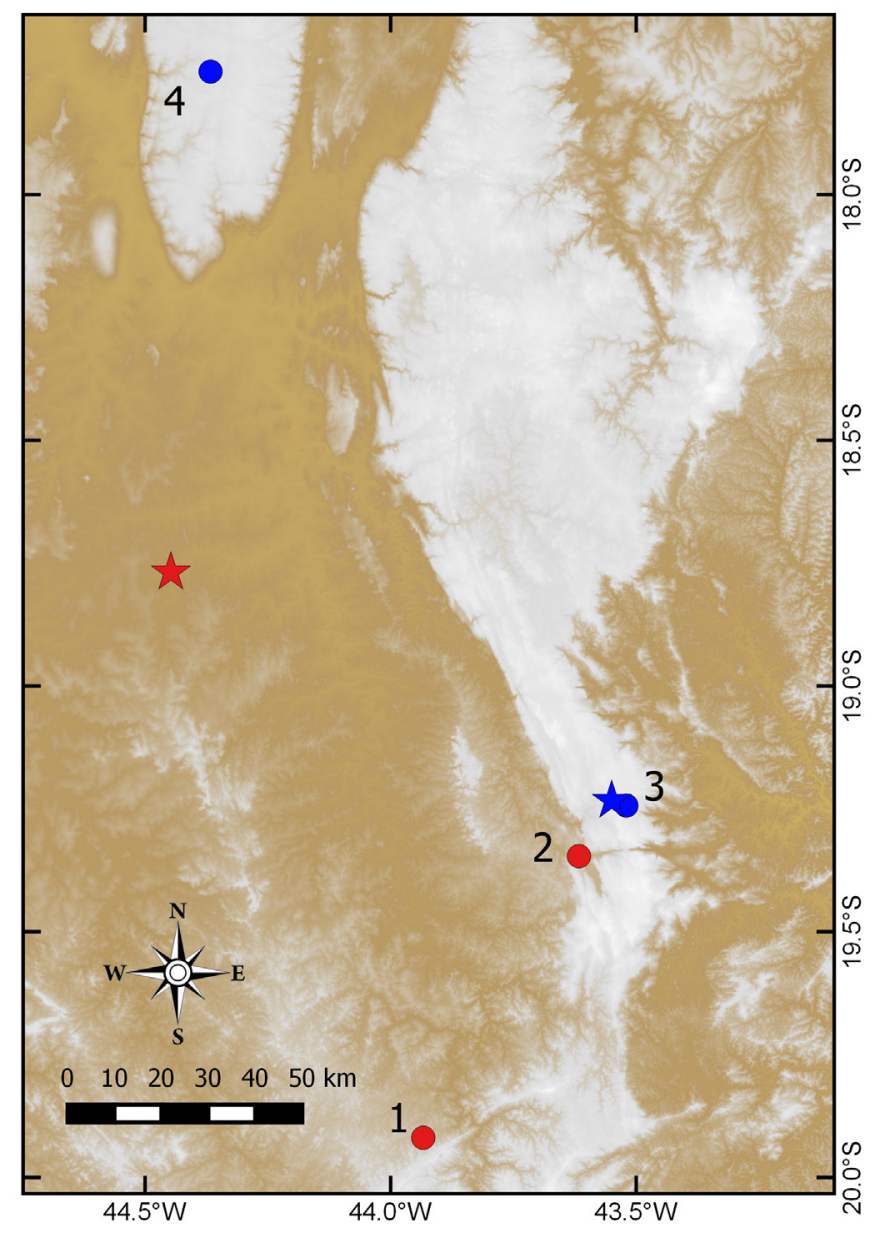

Fig. 1. Hypsometric map of the region highlighted on the map of Brazil (left), showing the samples of Pseudopaludicola matuta sp. nov. included in our molecular, morphological, and acoustic comparisons. The type locality of $P$. matuta sp. nov. in the municipality of Curvelo, is indicated with a red star. The map also highlights the known distribution (blue symbols) of P. mineira Lobo, 1994 and our record for this species. The type locality of P. mineira in the Serra do Cipó National Park is indicated with a blue star (Lobo 1994). Numbers: (1) Belo Horizonte; (2) lowlands of the Serra do Cipó National Park (near the park's headquarters, in a lowland area), municipality of Santana do Riacho; (3) highlands of the Serra do Cipó National Park, municipality of Santana do Riacho (our data); (4) Serra do Cabral, municipality of Buenópolis (Lobo 1994). All represented points are in the state of Minas Gerais, Brazil. Legend also contains the altitude in meters of the hypsometric map. 
notes to calculate the $\mathrm{CV}$ values of the species, not the introductory notes. The average was calculated for each trait from individual male $\mathrm{CV}$ values. Acoustic traits with low within-male $\mathrm{CV}$ values (usually less than 5\%) were classified as static and traits with higher values (usually greater than $12 \%$ ) as dynamic (Gerhardt 1991). We established one note per minute measurement for each analysed male; therefore, we checked the variability of this temporal trait through between-male coefficient of variation. Gerhardt (1991) reported that between-male coefficients of variation of static acoustic properties were less than $11 \%$, whereas coefficients of variation of dynamic properties exceeded $15 \%$.

We recorded 23 males of the new species in the municipality of Curvelo, state of Minas Gerais. We recorded seven males of the new species from the southern foothills of the Serra do Cipó National Park (lowland area, 797 m a.s.1.), municipality of Santana do Riacho, Minas Gerais. In addition, we analysed one recording (FNJV 31921) of a male from Pampulha, municipality of Belo Horizonte, Minas Gerais, identified previously as P. mineira and recorded by Werner C. A. Bokermann on 10 Feb. 1965. For acoustic comparison, we recorded and analysed seven topotypical males of $P$. mineira from rupestrian grasslands (1294 m a.s.l.) of the Serra do Cipó National Park. Additionally, we also analysed two recordings (FNJV 32050, 31899) of two topotypical males of $P$. mineira recorded by Werner C. A. Bokermann and Ivan Sazima.

The sound files are deposited in the Arquivo Sonoro da Coleção de Anuros da Universidade Federal de Uberlândia at UFU, Minas Gerais, Brazil and in the Fonoteca Neotropical Jacques Vielliard (FNJV) at Universidade Estadual de Campinas, São Paulo, Brazil. Voucher specimens for call recordings and further details of the analysed sound files are given in Supplementary File 1. Voucher specimens for call recordings and GenBank are ZUEC 24303-4, 24308, 24324, and 24327 (new species); and ZUEC 24330-1 (P. mineira).

\section{Statistical analysis}

We sought for discrimination between the new species and P. mineira by applying the randomForest (RF) model (randomForest v. 4.6-12 package; Liaw \& Wiener 2002) considering the morphometric and acoustic data separately. The randomForest algorithm (Breiman 2001) constructs many (generally 1000) classification trees using bootstrap samples of the data (each split using the best predictors among those randomly chosen at each node) then generating classifiers and aggregating results by voting to classes (further details in Liaw \& Wiener 2002). The RF results include an estimate of distances among the objects and a Multidimensional Scaling Analysis (MDS). This analysis can be plotted with the "proximityPlot" function of the package 'rfPermute' v. 2.1.5 (Archer 2016), which also allows the results to be displayed graphically. Analyses were conducted in R.

For the multivariate analysis and statistical tests we used all the morphometric features of adult males detailed above. For the acoustic analyses, we used note duration, internote interval, number of pulses per note, pulse duration, interpulse interval, pulse rate, note rate, and peak of dominant frequency. As environmental variables influence acoustic traits of anurans (Köhler et al. 2017), we incorporated air temperature as a continuous variable in our multivariate analyses. For the multivariate analysis and statistical tests we used the averaged values of each adult male. Acoustic and morphometric traits were tested for statistical significance of differences between species using the Exact Wilcoxon Mann Whitney Rank Sum Test, function "wilcox_test" of the package Coin (Resampling Statistics model; Hothorn et al. 2008) in $\mathrm{R}$.

\section{Phylogenetic inference and genetic distances}

We generated new sequence data for 11 specimens: nine of the new species (four from the type locality and five from southern foothills of the Serra do Cipó National Park), and two specimens of P. mineira from the type locality (Supplementary File 2). We extracted total DNA using a standard ammonium 
acetate precipitation method (Maniatis et al. 1982; adapted as in Lyra et al. 2017) and amplified two mitochondrial fragments (12S rRNA and 16S rRNA genes). For the 12S fragment, we used primers 12SL48 and 12S-H978 (Walker et al. 2018), and for the 16S fragment, primers 12L13 (Feller \& Hedges 1998), H10 (Hedges 1994), 16Sa-L and 16Sb-H (Kessing et al. 1989). PCR products were purified by enzymatic reaction and sent to Macrogen Inc. South Korea for sequencing. The new DNA sequences were quality trimmed and assembled using Geneious V.6 (Biomatter).

For phylogenetic inference we used MAFFT v. 7.25 (Katoh \& Standley 2013; default parameters) to align the new sequences with the sequences available for Pseudopaludicola spp., including 10 outgroups (Supplementary File 2). Phylogenetic analyses were performed under Bayesian Inference (BI) and Maximum Likelihood (ML) with the software MrBayes v. 3.2.6 (Ronquist et al. 2012) and PhyML v. 3.0 (Guindon et al. 2010), respectively.

The BI analysis was performed using two independent runs of 10 million generations, starting with random trees and four Markov chains (one cold), sampled every 1000 generations. We used GTR + Gamma as evolution model, selected in PartitionFinder (Lanfear et al. 2012) under the Bayesian Information Criterion (BIC). Twenty-five percent of generations and trees were discarded as 'burnin' and runs were considered convergent if standard deviation of split frequencies was lower than 0.01 . Analyses were run at the CIPRES Science Gateway (Miller et al. 2010). The ML analysis was conducted online using Smart Model Selection option (Lefort et al. 2017; available at http://www.atgc-montpellier.fr/phyml-sms/), which includes automatic selection of the best-fit substitution model for a given alignment. Tree searching was improved using Nearest Neighbor Interchanges (NNIs) and branch support estimated using aLRT SH-like tests. The consensus tree was edited in FigTree v. 1.4.2 (http://tree.bio.ed.ac.uk/software/figtree).

The average genetic distances within and between species were calculated for the $16 \mathrm{~S}$ fragment flanked by primers $16 \mathrm{Sa}-\mathrm{L}$ and $16 \mathrm{Sb}-\mathrm{H}$, since this fragment was available for all samples included in the analyses. Estimates were done using the alignment generated in MAFFT v.7.25 imported in MEGA v.6 (Tamura et al. 2013), and using uncorrected p-distance with pairwise deletion and variance estimated by bootstrap method (1000 replicates).

\section{Results}

Class Amphibia Linnaeus, 1758

Order Anura Fischer von Waldheim, 1813

Family Leptodactylidae Werner, 1896 (1838)

Subfamily Leiuperinae Bonaparte, 1850

Genus Pseudopaludicola Miranda-Ribeiro, 1926

Pseudopaludicola matuta sp. nov. urn:lsid:zoobank.org:act:DF080E14-2F88-45CC-876B-147D2D06C6D9

Figs 2-5, Tables 1-4

Pseudopaludicola sp. - Carvalho (2012): 52, Natural History Section.

Pseudopaludicola mineira from Pampulha, Belo Horizonte, Minas Gerais - Andrade et al. 2018: 87, Discussion Section.

\section{Diagnosis}

Pseudopaludicola matuta sp. nov. is assigned to the genus Pseudopaludicola by having a hypertrophied antebrachial tubercle (see Lynch 1989, Lobo 1995). The new species is characterized by the following combination of characters: (1) small size (SVL 12.8-14.2 mm in adult males); (2) absence of both, 
enlarged palpebral tubercles and an enlarged conical tubercle on heel; (3) relatively short hind limbs (tibiotarsal articulation only reaching the posterior margin of the eye); and (4) advertisement call composed of regular series of stereotyped two-pulsed notes, with notes having a short duration and emitted at a higher rate (notes per minute).

\section{Differential diagnosis}

Pseudopaludicola matuta sp. nov. is promptly distinguished from the species of the $P$. saltica group ( $P$. saltica, $P$. murundu, and $P$. jaredi) by having relatively short hind limbs; i.e., the tibiotarsal articulation reaches the posterior margin of the eye in the new species, whereas it reaches the tip of the snout in species of the P. saltica group (Andrade et al. 2016).

Pseudopaludicola matuta sp. nov. is distinguished from species of the P. pusilla group (P. boliviana, P. ceratophyes, . llanera, P. pusilla, and P. motorzinho) by the absence of either T-shaped terminal phalanges or expanded toe tips (disks or pads). The tips of the phalanges of the new species are not T-shaped; they are similar in shape to those of P. falcipes (fig. 2B in Cardozo \& Suárez 2012). The new species is also distinguished from $P$. ceratophyes by the absence of an enlarged palpebral tubercle (Lynch 1989). Pseudopaludicola matuta sp. nov. differs from P. boliviana and P. motorzinho by the absence of an enlarged, conical tubercle on the heel (Pansonato et al. 2016).

Pseudopaludicola matuta sp. nov. has an advertisement call composed of series of notes with two nonconcatenated pulses each (Fig. 4A-B); therefore, it is promptly distinguished from all species with advertisement call composed of non-pulsed notes: P. canga Giaretta \& Kokubum, 2003 (Giaretta \& Kokubum 2003; Pansonato et al. 2012; Carvalho et al. 2015a), P. giarettai (Carvalho 2012; Carvalho et al. 2015b), P. hyleaustralis Pansonato, Morais, Ávila, Kawashita-Ribeiro, Strüssmann \& Martins, 2012 (Pansonato et al. 2012), P. facureae (Andrade \& Carvalho 2013; Carvalho et al. 2015a), and P. parnaiba Roberto, Cardozo \& Ávila, 2013 (Roberto et al. 2013; Carvalho et al. 2015a); and from all species with notes with concatenated pulses (= lack of interpulse interval; sensu Magalhães et al. 2014): P. mystacalis [12-14 concatenated pulses; Pansonato et al. 2013], P. boliviana [3-6; Duré et al. 2004], P. ibisoroca Pansonato, Veiga-Menoncello, Mudrek, Jansen, Recco-Pimentel, Martins \& Strüssmann, 2016 [3-12; Pansonato et al. 2016], and P. motorzinho [2-6; Pansonato et al. 2016].

Pseudopaludicola matuta sp. nov. is distinguished from other congeners with notes with non-concatenated pulses (values within square brackets "[ ]") by the following acoustic traits: P. ameghini (Cope, 1887) has longer note duration (27-52 [60-121] ms), higher number of pulses per note (2 [3-5]), and lower note rate (542-1101 [348-452] notes per minute) (Andrade et al. 2017a); P. ternetzi Miranda-Ribeiro, 1937 has higher number of pulses per note [3-6] (Andrade et al. 2017a); P. atragula Pansonato, Mudrek, Veiga-Menoncello, Rossa-Feres, Martins \& Strüssmann, 2014 has longer note duration [300-700 ms], higher number of pulses per note [9-36], and lower note rate [42-98 notes per minute] (Pansonato et al. 2014). The three species of the $P$. saltica species group have lower note rate [180-480 notes per minute, combined values], and vary highly the number of pulses in their notes (2-7 pulses per note, combined values; Andrade et al. 2016). Pseudopaludicola falcipes and P. restinga Cardozo, Baldo, Pupin, Gasparini \& Haddad, 2018 have lower note rates [238-535 notes per minute] (Andrade et al. 2018; Cardozo et al. 2018). Pseudopaludicola pocoto Magalhães, Loebmann, Kokubum, Haddad \& Garda, 2014 and P. florencei Andrade, Haga, Lyra, Leite, Kwet, Haddad, Toledo \& Giaretta, 2018 have stereotyped three-pulsed notes along their series of notes, longer note duration [108-397 ms, combined values], and lower note rate [100-297 notes per minute, combined values] (Magalhães et al. 2014; Andrade et al. 2017b, 2018). In comparison with the phylogenetically close related species, the new species is distinguished from $P$. mineira by having shorter note duration [50-114 ms] and lower note rate [282-485 notes per minute] (Table 2). The advertisement call of $P$. ceratophyes, $P$. llanera, and P. pusilla are unknown; however, there are strong morphological differences among them and P. matuta sp. nov. 
Table 1. Morphometry of the type series and additional specimens of Pseudopaludicola matuta sp. nov., and of specimens of $P$. mineira Lobo, 1994 (including types and additional specimens designated by Lobo 1994). Values presented in millimeters as mean \pm standard deviation (minimum-maximum); $n=$ number of measured specimens.

\begin{tabular}{|c|c|c|c|c|c|c|}
\hline \multirow[b]{2}{*}{ Characters } & \multicolumn{3}{|c|}{ Type series } & \multicolumn{2}{|c|}{ Additional specimens } & \multirow{2}{*}{$\begin{array}{c}\text { P. mineira } \\
\text { Males } \\
(\mathrm{n}=38)\end{array}$} \\
\hline & Holotype & $\begin{array}{c}\text { Males } \\
(\mathrm{n}=15)\end{array}$ & $\begin{array}{c}\text { Females } \\
(\mathrm{n}=5)\end{array}$ & $\begin{array}{l}\text { Males } \\
(\mathrm{n}=3)\end{array}$ & $\begin{array}{c}\text { Females } \\
(\mathrm{n}=3)\end{array}$ & \\
\hline Snout-vent length & 13.0 & $\begin{array}{c}13.5 \pm 0.4 \\
(12.8-14.3)\end{array}$ & $\begin{array}{c}15.4 \pm 0.6 \\
(14.7-16.0)\end{array}$ & $\begin{array}{c}13.4 \pm 0.3 \\
(13.1-13.6)\end{array}$ & $\begin{array}{c}15.0 \pm 0.3 \\
(14.7-15.3)\end{array}$ & $\begin{array}{c}13.6 \pm 0.7 \\
(12.2-14.5)\end{array}$ \\
\hline Head length & 4.1 & $\begin{array}{l}3.9 \pm 0.2 \\
(3.6-4.3)\end{array}$ & $\begin{array}{l}4.4 \pm 0.2 \\
(4.2-4.6)\end{array}$ & $\begin{array}{l}3.8 \pm 0.2 \\
(3.7-4.0)\end{array}$ & $\begin{array}{l}4.4 \pm 0.2 \\
(4.2-4.5)\end{array}$ & $\begin{array}{l}3.5 \pm 0.2 \\
(3.2-4.0)\end{array}$ \\
\hline Head width & 4.7 & $\begin{array}{l}4.8 \pm 0.1 \\
(4.5-4.9)\end{array}$ & $\begin{array}{l}5.4 \pm 0.2 \\
(5.2-5.5)\end{array}$ & $\begin{array}{l}4.6 \pm 0.2 \\
(4.5-4.8)\end{array}$ & $\begin{array}{l}5.1 \pm 0.2 \\
(4.9-5.2)\end{array}$ & $\begin{array}{l}4.6 \pm 0.2 \\
(4.4-4.9)\end{array}$ \\
\hline Eye diameter & 1.6 & $\begin{array}{l}1.5 \pm 0.1 \\
(1.4-1.6)\end{array}$ & $\begin{array}{l}1.6 \pm 0.1 \\
(1.5-1.7)\end{array}$ & $\begin{array}{l}1.5 \pm 0.0 \\
(1.5-1.5)\end{array}$ & $\begin{array}{l}1.7 \pm 0.1 \\
(1.6-1.7)\end{array}$ & $\begin{array}{l}1.5 \pm 0.1 \\
(1.4-1.7)\end{array}$ \\
\hline Interorbital distance & 1.5 & $\begin{array}{l}1.4 \pm 0.1 \\
(1.2-1.7)\end{array}$ & $\begin{array}{l}1.7 \pm 0.1 \\
(1.6-1.8)\end{array}$ & $\begin{array}{l}1.5 \pm 0.1 \\
(1.4-1.5)\end{array}$ & $\begin{array}{l}1.6 \pm 0.1 \\
(1.5-1.6)\end{array}$ & $\begin{array}{l}1.4 \pm 0.1 \\
(1.2-1.5)\end{array}$ \\
\hline Eye-nostril distance & 1.1 & $\begin{array}{l}1.1 \pm 0.1 \\
(0.9-1.4)\end{array}$ & $\begin{array}{l}1.2 \pm 0.2 \\
(1.0-1.4)\end{array}$ & $\begin{array}{l}1.2 \pm 0.1 \\
(1.1-1.2)\end{array}$ & $\begin{array}{l}1.3 \pm 0.1 \\
(1.2-1.4)\end{array}$ & $\begin{array}{l}1.1 \pm 0.1 \\
(0.9-1.2)\end{array}$ \\
\hline Snout length & 2.1 & $\begin{array}{l}2.0 \pm 0.1 \\
(1.7-2.2)\end{array}$ & $\begin{array}{l}2.3 \pm 0.2 \\
(2.1-2.5)\end{array}$ & $\begin{array}{l}2.0 \pm 0.1 \\
(2.0-2.1)\end{array}$ & $\begin{array}{l}2.2 \pm 0.1 \\
(2.1-2.3)\end{array}$ & $\begin{array}{l}2.0 \pm 0.1 \\
(1.8-2.2)\end{array}$ \\
\hline Internarial distance & 1.3 & $\begin{array}{l}1.2 \pm 0.1 \\
(0.9-1.4)\end{array}$ & $\begin{array}{l}1.3 \pm 0.1 \\
(1.2-1.5)\end{array}$ & $\begin{array}{l}1.2 \pm 0.1 \\
(1.1-1.2)\end{array}$ & $\begin{array}{l}1.3 \pm 0.1 \\
(1.3-1.4)\end{array}$ & $\begin{array}{l}1.0 \pm 0.1 \\
(0.9-1.1)\end{array}$ \\
\hline Hand length & 3.7 & $\begin{array}{l}3.7 \pm 0.2 \\
(3.3-4.0)\end{array}$ & $\begin{array}{l}4.2 \pm 0.3 \\
(3.7-4.4)\end{array}$ & $\begin{array}{l}3.7 \pm 0.3 \\
(3.5-4.0)\end{array}$ & $\begin{array}{l}4.2 \pm 0.2 \\
(4.0-4.3)\end{array}$ & $\begin{array}{l}3.7 \pm 0.2 \\
(3.2-4.0)\end{array}$ \\
\hline Thigh Length & 6.7 & $\begin{array}{l}6.3 \pm 0.2 \\
(5.9-6.7)\end{array}$ & $\begin{array}{l}7.0 \pm 0.5 \\
(6.2-7.6)\end{array}$ & $\begin{array}{l}6.2 \pm 0.1 \\
(6.1-6.2)\end{array}$ & $\begin{array}{l}7.1 \pm 0.3 \\
(6.8-7.4)\end{array}$ & $\begin{array}{l}6.5 \pm 0.3 \\
(6.0-7.1)\end{array}$ \\
\hline Tibia length & 7.2 & $\begin{array}{l}6.9 \pm 0.4 \\
(6.2-7.5)\end{array}$ & $\begin{array}{l}7.8 \pm 0.2 \\
(7.5-8.0)\end{array}$ & $\begin{array}{l}6.6 \pm 0.2 \\
(6.4-6.8)\end{array}$ & $\begin{array}{c}7.7 \pm 0.3 \\
(7.4-8.0)\end{array}$ & $\begin{array}{l}7.2 \pm 0.3 \\
(6.6-7.7)\end{array}$ \\
\hline Tarsus length & 3.9 & $\begin{array}{l}3.7 \pm 0.3 \\
(3.4-4.1)\end{array}$ & $\begin{array}{l}4.4 \pm 0.2 \\
(4.1-4.6)\end{array}$ & $\begin{array}{l}3.8 \pm 0.1 \\
(3.7-3.9)\end{array}$ & $\begin{array}{l}4.4 \pm 0.4 \\
(4.0-4.8)\end{array}$ & $\begin{array}{l}3.7 \pm 0.2 \\
(3.3-4.2)\end{array}$ \\
\hline Foot length & 7.8 & $\begin{array}{l}7.2 \pm 0.3 \\
(6.4-7.7) \\
\end{array}$ & $\begin{array}{l}8.1 \pm 0.4 \\
(7.6-8.5) \\
\end{array}$ & $\begin{array}{l}7.3 \pm 0.1 \\
(7.2-7.4)\end{array}$ & $\begin{array}{l}8.3 \pm 0.4 \\
(7.9-8.6)\end{array}$ & $\begin{array}{l}7.3 \pm 0.3 \\
(6.5-7.8) \\
\end{array}$ \\
\hline
\end{tabular}

In relation to the most closely related species, $P$. mineira, the randomForest multivariate approach applied to morphometric data indicated a broad overlap between the two partitions (Fig. 5A-B), with a considerable classification error (Table 3). We found no statistical significance in any trait. Therefore, we were unable to distinguish $P$. matuta sp. nov. from P. mineira based on morphometric or any other feature of external morphology or coloration. In contrast, the RandomForest multivariate approach on acoustic data highlighted a full segregation between $P$. matuta sp. nov. and P. mineira (Table 3, Fig. 5C), without any classification error. Pulse rate, note duration, notes per minute, and interpulse interval are the main sources of variation in both variable importance measurements (Fig. 5D). The trait of notes per minute for P. mineira did not overlap the values for the new species either. It is noteworthy that the air temperature overlapped at the time of the field recordings for both species (Table 2), and is among the variables that least explained the variation of the dataset, with low importance measures as produced by randomForest (Fig. 5D). Therefore, we do not attribute this found acoustic difference to the influence of the air temperature. In addition, there was only a slight overlap between both species in note duration (see Table 2). The new species can be significantly differentiated from P. mineira in the following traits: note duration, internote interval, interpulse interval, pulse rate, and dominant frequency (for all these traits, Wilcoxon-Mann-Whitney Tests had $P<0.01$ ). 


\section{Etymology}

The feminine noun matuta in Brazilian Portuguese means rustic, provincial, related to those who live in the countryside.

\section{Type material}

\section{Holotype}

BRAZIL: adult $\partial^{\lambda}$, Minas Gerais, municipality of Curvelo, Sítio Mato do Engenho, $18^{\circ} 46^{\prime} 07.6^{\prime \prime} \mathrm{S}$,

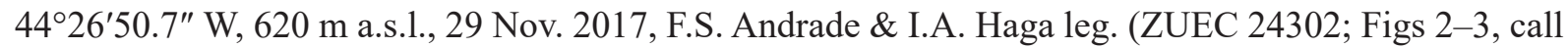
voucher).

\section{Paratopotypes}

BRAZIL: 12 adult $\hat{\partial} \sigma^{\hat{D}}$, same collection data as the holotype (ZUEC 24303-6, 24308-10, 24313, 243158); 3 adult $\widehat{\partial} \widehat{\partial}$, same locality as holotype, 21 Feb. 2011, T.R. Carvalho leg. (AAG-UFU 0308, 0386-7); 5 adult $q$ 오, same collection data as the holotype (ZUEC 24307, 24311-2, 24314, 24323).

\section{Type locality}

BRAZIL: Minas Gerais, municipality of Curvelo, Sítio Mato do Engenho, $18^{\circ} 46^{\prime} 07.6^{\prime \prime}$ S, $44^{\circ} 26^{\prime} 50.7^{\prime \prime}$ $\mathrm{W}, 620 \mathrm{~m}$ a.s.1.

\section{Other material examined}

BRAZIL: 3 adult $\hat{\delta} \widehat{\partial}$, Minas Gerais, municipality of Santana do Riacho, district of Serra do Cipó, southern foothills of Serra do Cipó National Park, near Lagoa da Capivara (19²0'46.30” ' S, 4336 '59.62" W, 797 m a.s.1.), 2-3 Dec. 2017, F.S. Andrade \& I.A. Haga leg. (ZUEC 24324, 24327, 24329); 3 adult 우우, same collection data as previous (ZUEC 24325-6, 24328).

\section{Description of the holotype}

Body elliptic and broad (Table 1, Fig. 2A-B). Head elliptical, slightly wider than long. Snout subovoid in dorsal view and rounded in profile (Fig. 2C-D). Eye not protuberant. Eye diameter almost equal to the interorbital distance. Interorbital area flat. Pupil rounded. Upper eyelid without tubercles. Nostril not protuberant and closer to the snout tip than to the eye. Canthus rostralis rounded, smooth. Loreal region slightly concave. Single subgular vocal sac, externally expanded and with discrete longitudinal folds. Choanae rounded, well separated from each other. Vocal slits present. Tympanum indistinct. A discrete tympanic ridge from behind the eye to the proximal portion of the arm. Mouth opening ventral. Vomerine teeth absent. Tongue elliptical, longer than wide, posteriorly free, without pigmentation at its base. Flank with discrete granules. One ovoid antebrachial tubercle present in the first quarter of the forearm and a second ovoid tubercle closer to elbow. Finger and toe tips not expanded. Outer and inner metacarpal tubercles well-defined, outer metacarpal tubercle ovoid and inner metacarpal tubercle rounded. Fingers with single and rounded subarticular tubercles. Supernumerary tubercles absent on palm of hand. Thumb with a keratinized, light brown nuptial pad, extending from the base of the hand to the proximal limit of the terminal phalanx, covering almost the entire external portion of the finger. Webbing absent between fingers. Relative finger lengths, when adpressed one to another: $\mathrm{I}<\mathrm{II}<\mathrm{IV}<$ III (Fig. 2E). Outer metatarsal tubercle well defined, conical. Inner metatarsal tubercle elliptical. The internal metatarsal tubercle larger than the external. Toes with well-defined, single, enlarged, and rounded subarticular tubercles. Supernumerary tubercles absent on sole of the foot. Toes webbed basally and fringed along their sides to almost their tips. Fringes developed on all toes (mainly II, III, IV, and V). External fringe on Toe V continues almost to the outer metatarsal tubercle. Well-developed fold from internal metatarsal tubercle to the mid-ventral tarsus, ending in a tarsal tubercle poor protuberant. Relative toe lengths, when adpressed one to another: $\mathrm{I}<\mathrm{II}<\mathrm{V}<\mathrm{III}<\mathrm{IV}$ (Fig. 2F). Hind limb robust and moderately long with the tibiotarsal articulation just reaching the posterior margins of eye. Thigh shorter 

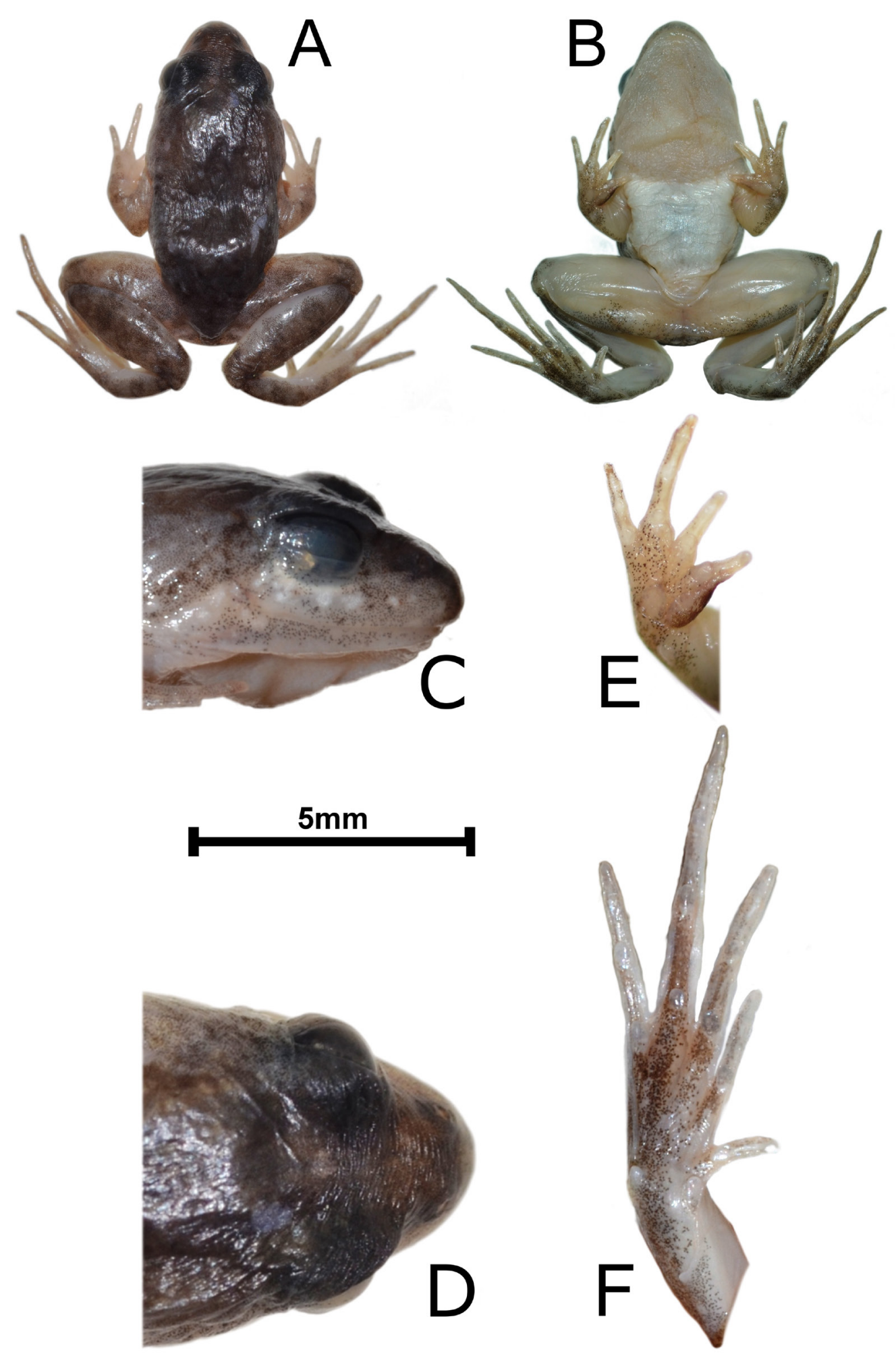

Fig. 2. Pseudopaludicola matuta sp. nov. holotype, adult $\widehat{\partial}$ (ZUEC 24302, SVL $=13.0 \mathrm{~mm})$. A. Dorsal view. B. Ventral view. C. Head, lateral view. D. Head, dorsal view. E. Hand, ventral view. F. Foot, ventral view. Scale bar $=5 \mathrm{~mm}$. 
than tibia. Foot longer than thigh. Foot longer than tibia. Tubercle absent on heel. Belly skin smooth. Abdominal fold present and complete. Dorsal surfaces of head, body, and limbs smooth. Cloacal region smooth (Fig. 2B). Measurements of the holotype presented in Table 1.

\section{Color pattern of the holotype in preservative}

Dorsum grayish with dark gray, white, and brown blotches. Belly whitish (unpigmented). Throat light beige, unpigmented. Throat darker than belly. Dorsum darker than the dorsal surfaces of limbs. Region between upper lip and eye with several rounded white blotches. Ventral faces of arms and
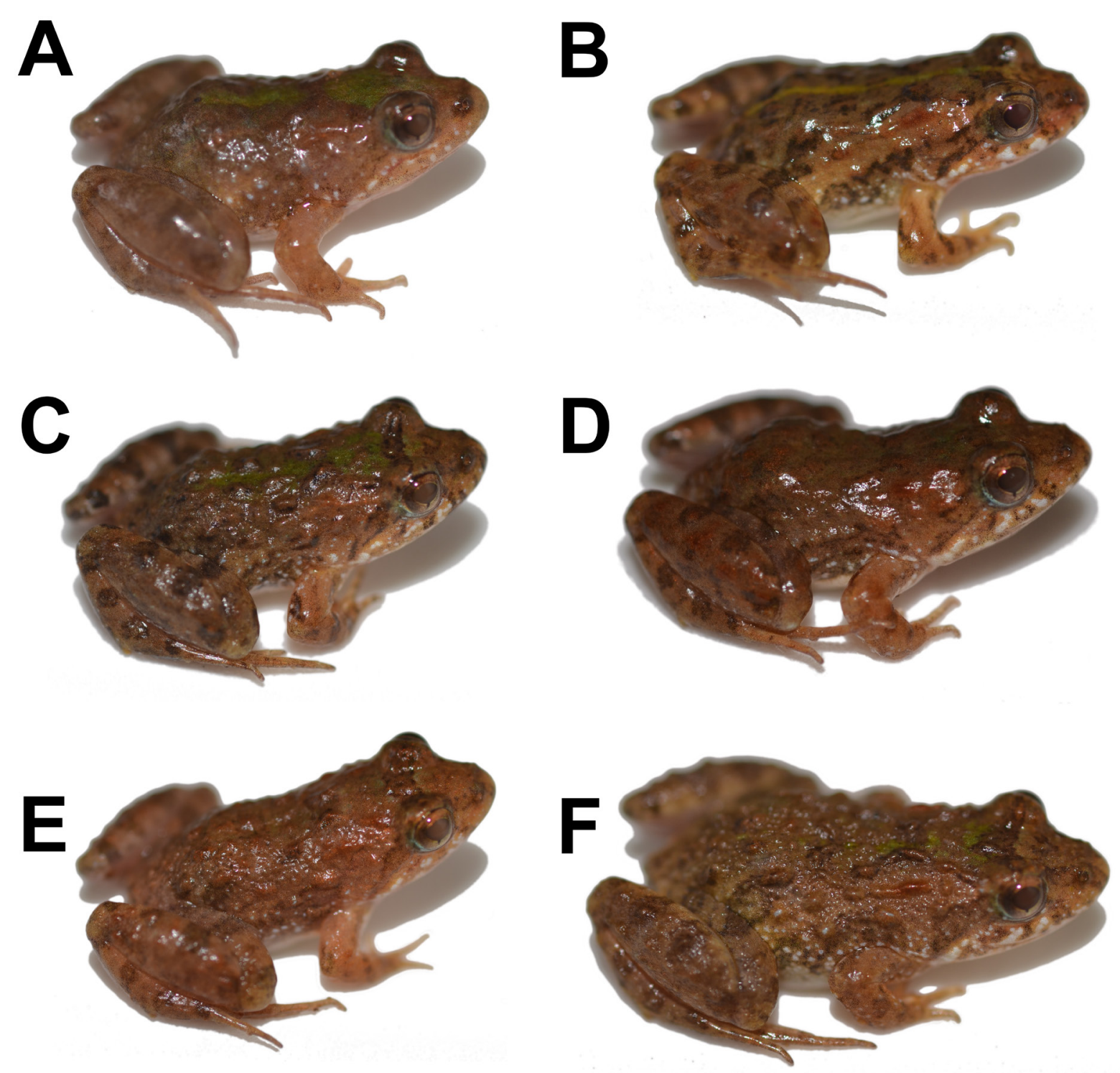

Fig. 3. Holotype and five paratypes of Pseudopaludicola matuta sp. nov. in life. A. Specimen ZUEC 24302 (holotype, adult $\widehat{\partial}$, call voucher; $\mathrm{SVL}=13.0 \mathrm{~mm}$ ). B. Specimen ZUEC 24304 (adult $\widehat{\partial}$, call and GenBank voucher; SVL = $13.3 \mathrm{~mm}$ ). C. Specimen ZUEC 24303 (adult $\widehat{\jmath}$, call and GenBank voucher; $\mathrm{SVL}=12.8 \mathrm{~mm}$ ). D. Specimen ZUEC 24305 (adult $\delta$ and call voucher; $\mathrm{SVL}=13.4 \mathrm{~mm}$ ). E. Specimen ZUEC 24308 (adult $\hat{\jmath}$, call and GenBank voucher; SVL = $13.5 \mathrm{~mm}$ ). F. Specimen ZUEC 24307 (adult $\uparrow$ and GenBank voucher; $\mathrm{SVL}=15.2 \mathrm{~mm}$ ). 
Table 2. Advertisement call traits of Pseudopaludicola matuta sp. nov. from the type locality, lowlands of the Serra do Cipó National Park (southern foothills), municipality of Santana do Riacho, and municipality of Belo Horizonte; and of P. mineira Lobo, 1994 from its type locality, in the highlands of Serra do Cipó; all in the Brazilian state of Minas Gerais. Mean \pm SD (minimum-maximum); $n=$ number of males recorded (number of analysed notes).

\begin{tabular}{|c|c|c|c|}
\hline \multirow{2}{*}{ Traits } & \multicolumn{2}{|c|}{ P. matuta sp. nov. } & \multirow{2}{*}{$\begin{array}{c}\text { P. mineira } \\
\text { Type locality } \\
\mathrm{n}=9(180)\end{array}$} \\
\hline & $\begin{array}{l}\text { Type locality } \\
\mathrm{n}=23(460)\end{array}$ & $\begin{array}{c}\text { Other localities } \\
\mathrm{n}=8(160)\end{array}$ & \\
\hline Call duration (s) & $\begin{array}{l}26.1 \pm 18.7 \\
(3.6-66.2)\end{array}$ & $\begin{array}{l}44.4 \pm 34.9 \\
(19.7-69.1)\end{array}$ & - \\
\hline Series of notes duration (s) & $\begin{array}{c}9.4 \pm 6.5 \\
(0.2-34.0)\end{array}$ & $\begin{array}{l}23.7 \pm 14.5 \\
(7.4-46.0)\end{array}$ & $\begin{array}{c}14.5 \pm 15.7 \\
(0.4-44.3)\end{array}$ \\
\hline Interseries interval (s) & $\begin{array}{l}0.6 \pm 0.5 \\
(0.2-2.0)\end{array}$ & $\begin{array}{l}0.6 \pm 0.3 \\
(0.3-0.8)\end{array}$ & $\begin{array}{c}1.9 \pm 0.0 \\
(0.3-10.9)\end{array}$ \\
\hline Series per call & $\begin{array}{l}3.4 \pm 2.0 \\
(1-9)\end{array}$ & $\begin{array}{c}2.5 \pm 0.7 \\
(1-3)\end{array}$ & - \\
\hline Note duration (ms) & $\begin{array}{c}37 \pm 3 \\
(27-46)\end{array}$ & $\begin{array}{c}41 \pm 4 \\
(34-52)\end{array}$ & $\begin{array}{c}69 \pm 8 \\
(50-114)\end{array}$ \\
\hline Internote interval (ms) & $\begin{array}{c}29 \pm 6 \\
(17-72)\end{array}$ & $\begin{array}{c}49 \pm 9 \\
(35-76)\end{array}$ & $\begin{array}{c}74 \pm 20 \\
(42-159)\end{array}$ \\
\hline Pulse duration (ms) & $\begin{array}{c}9 \pm 2 \\
(4-15)\end{array}$ & $\begin{array}{c}6 \pm 1 \\
(3-10)\end{array}$ & $\begin{array}{l}10 \pm 3 \\
(4-22)\end{array}$ \\
\hline Interpulse interval (ms) & $\begin{array}{c}18 \pm 3 \\
(11-31)\end{array}$ & $\begin{array}{c}30 \pm 4 \\
(22-40)\end{array}$ & $\begin{array}{c}47 \pm 10 \\
(5-94)\end{array}$ \\
\hline Notes per minute & $\begin{array}{c}928.6 \pm 85.1 \\
(738.0-1101.4)\end{array}$ & $\begin{array}{c}655.2 \pm 75.4 \\
(541.9-736.6)\end{array}$ & $\begin{array}{c}427.1 \pm 64.2 \\
(282.1-485.1)\end{array}$ \\
\hline Pulse rate & $\begin{array}{c}54.7 \pm 5.9 \\
(43.5-74.1)\end{array}$ & $\begin{array}{c}48.8 \pm 4.4 \\
(38.5-58.8)\end{array}$ & $\begin{array}{c}29.8 \pm 3.0 \\
(17.5-117.6)\end{array}$ \\
\hline Pulses per note & $\begin{array}{l}2.0 \pm 0.0 \\
(2-2)\end{array}$ & $\begin{array}{l}2.0 \pm 0.0 \\
(2-2)\end{array}$ & $\begin{array}{l}2.0 \pm 0.1 \\
(2-3)\end{array}$ \\
\hline Dominant frequency $(\mathrm{kHz})$ & $\begin{array}{l}4.5 \pm 0.2 \\
(3.9-5.1)\end{array}$ & $\begin{array}{l}4.7 \pm 0.1 \\
(4.6-5.0)\end{array}$ & $\begin{array}{l}3.8 \pm 0.2 \\
(3.6-4.3)\end{array}$ \\
\hline Minimum frequency $(\mathrm{kHz})$ & $\begin{array}{l}4.0 \pm 0.3 \\
(2.9-4.6)\end{array}$ & $\begin{array}{l}4.1 \pm 0.3 \\
(1.8-4.4)\end{array}$ & $\begin{array}{l}3.2 \pm 0.2 \\
(2.3-3.9)\end{array}$ \\
\hline Maximum frequency $(\mathrm{kHz})$ & $\begin{array}{l}4.9 \pm 0.2 \\
(4.4-5.5)\end{array}$ & $\begin{array}{l}5.1 \pm 0.1 \\
(4.9-5.2)\end{array}$ & $\begin{array}{l}4.2 \pm 0.1 \\
(4.0-4.5)\end{array}$ \\
\hline Air temperature $\left({ }^{\circ} \mathrm{C}\right)$ & $24.0-25.2$ & $20.5-23.0$ & $17.0-24.0$ \\
\hline
\end{tabular}

Table 3. Confusion matrix for two sister species of Pseudopaludicola based on morphometric and acoustic (values in bold) data by means of a Random Forests model. Settings: number of tree permutations $=1000$; number of variables tried at each split $=3.0$; error rates $=8.77 \% \mid \mathbf{0 . 0 0} \%$.

\begin{tabular}{lccc}
\hline & P. matuta sp. nov. & P. mineira & class.error \\
\hline P. matuta sp. nov. & $15 \mid \mathbf{3 1}$ & $4 \mid \mathbf{0}$ & $0.21 \mid \mathbf{0 . 0 0}$ \\
P. mineira & $1 \mid \mathbf{0}$ & $37 \mid \mathbf{9}$ & $0.03 \mid \mathbf{0 . 0 0}$ \\
\hline
\end{tabular}




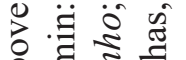
का

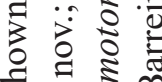
政 क्षे के (⿻) छ $\mathbb{2} \approx$ 2. 2 क

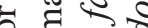
a 宊 西

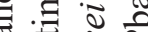

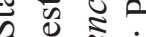
एं के

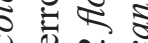

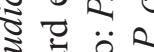
쥼 o 焉 范 है जु is 0 政 . 两 . ○ 过 记 政次 匹 क 专 0 o O Q Q के

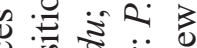
के

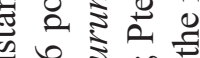
을 in $\equiv$ क्ष

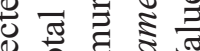
응

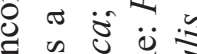

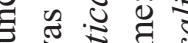
उ

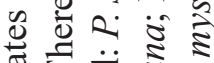
西要 म बं 2 ह II 80 $\div .000$

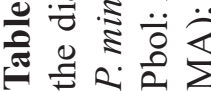

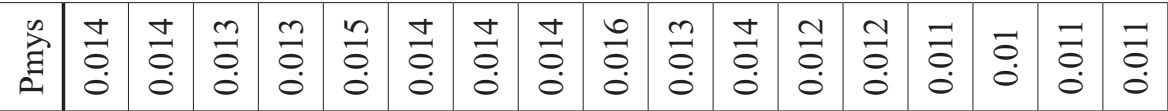

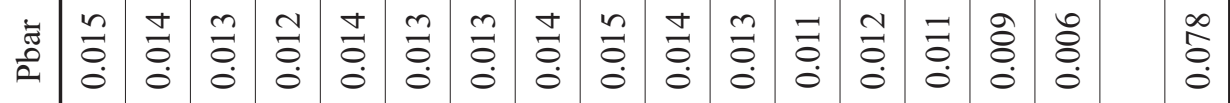

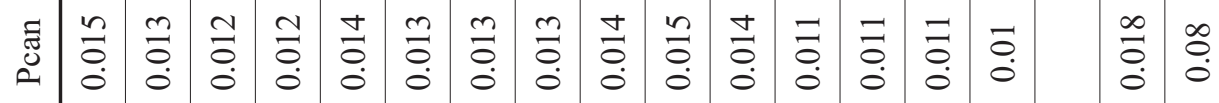

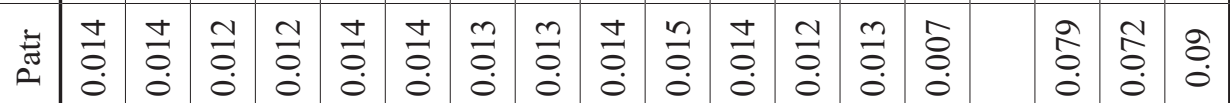

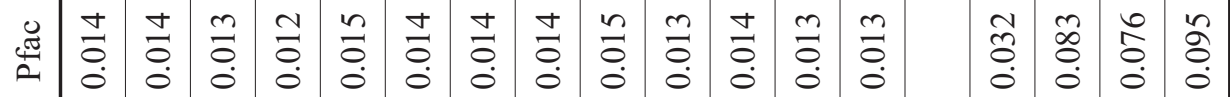

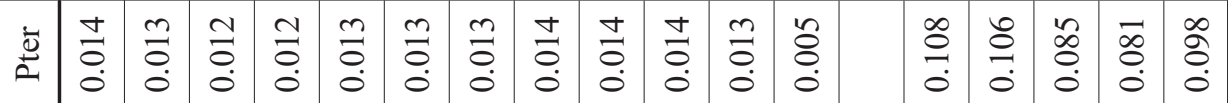

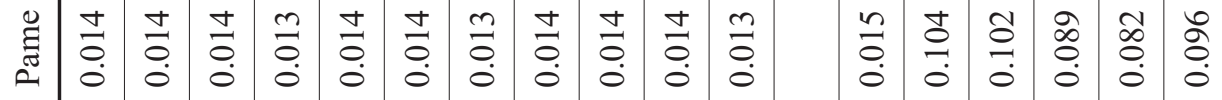

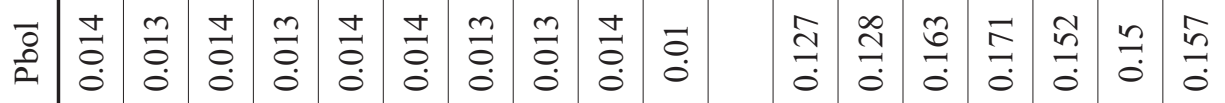

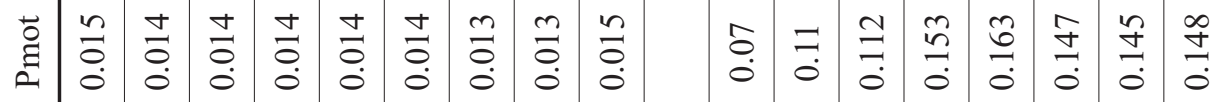

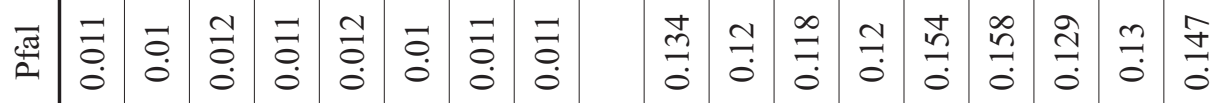

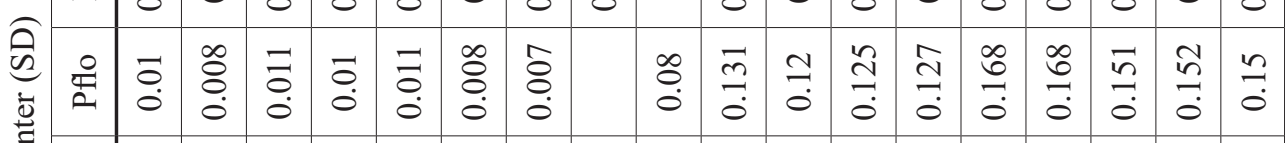

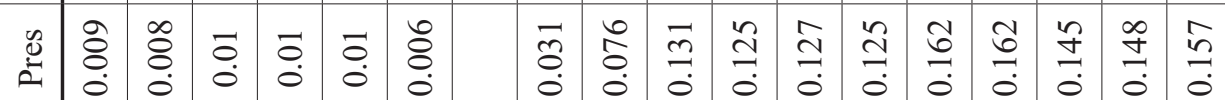

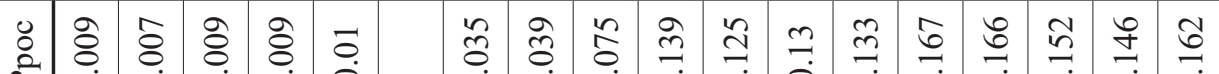

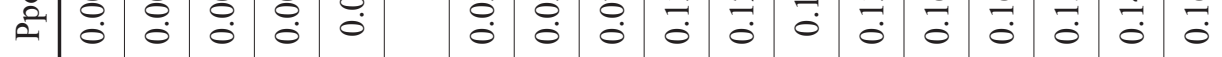

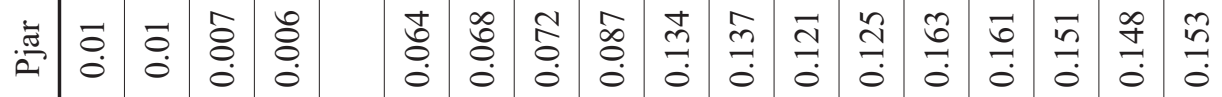

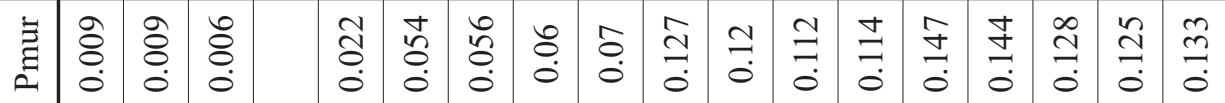

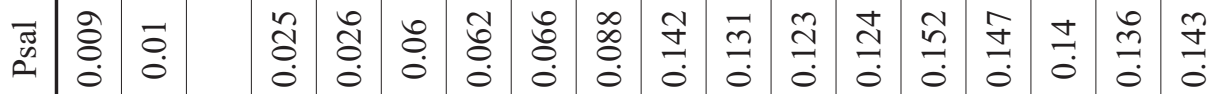
들 ₹ : :

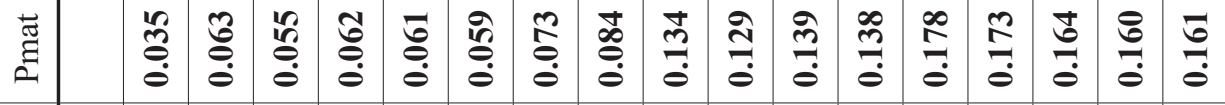

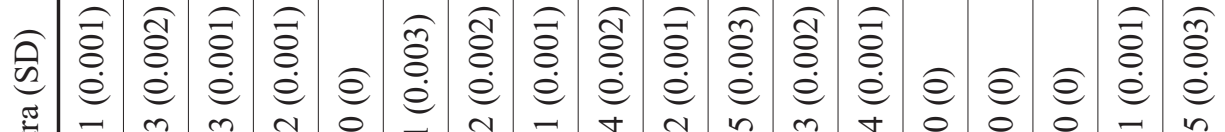

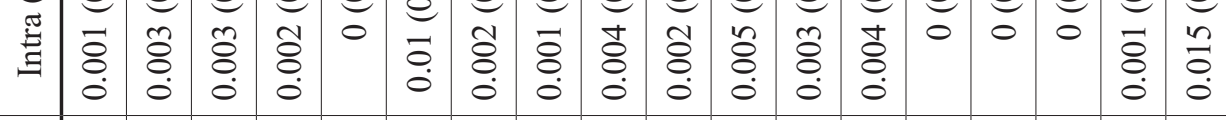

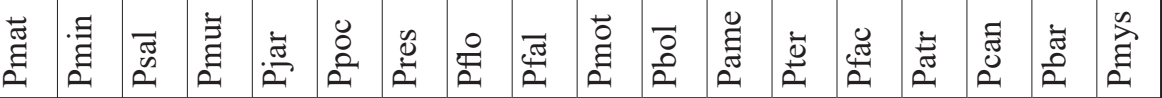


legs unpigmented, except that of the thigh (slight pigmented). Palm of hand pigmented. Sole of foot pigmented and darker than hands, arms, and hind limbs. Color of the sole of the foot similar to that of the dorsum of hind limb. Dorsal faces of arms light brown with several dark brown blotches. Dorsal faces of legs light grayish with scattered brown blotches. Dark brown nuptial pads (Fig. 2).

\section{Variation in the type series}

Dorsal surface of body varies from dark gray to dark brown, with black or dark brown irregular blotches (Fig. 3). The specimens ZUEC 24303-18 and 24323 have transverse stripes on thighs, shanks, and feet. The specimens ZUEC 24304, 24310-3, 24317-8 have a well-defined light vertebral line. The specimens ZUEC 24304, 24310-3, 24315, 24317-8, and 24323 have dorsolateral stains on body, from posterior corner of eyes to almost the region of insertion of legs. The specimens ZUEC 24304-5, 24307-8, 24311, 24315-8, 24323 also have white blotches on the region between the posterior corner of eyes and the region of insertion of arms. The specimen ZUEC 24312 has the region between upper lip and eye with alternating vertical gray and light beige stripes. Females have a more robust body and lack nuptial pads, vocal sac, and vocal slits.

\section{Advertisement call}

Pseudopaludicola matuta sp. nov. emits the advertisement call with highly variable duration (3.6$66.2 \mathrm{~s}$ ), consisting of series of stereotyped two-pulsed notes (1-9 series of two-pulsed notes per call) that lasts $0.2-34.0 \mathrm{~s}$, separated by intervals of $0.2-1.9 \mathrm{~s}$ (Fig. 4A). Before the emission of the series of stereotyped two-pulsed notes, $1-10$ (mean $=4.4, \mathrm{SD}=3.3$ ) isolated pulsed notes with irregular structure, duration, interval, and number of pulses are emitted, herein referred to as introductory notes (Fig. 4A). Introductory notes last 29-117 ms (mean 64, SD = 24), separated by intervals of 37-495 ms $($ mean $=213, \mathrm{SD}=111)$, and are composed of $2-5$ non-concatenated pulses (mean $=3.3, \mathrm{SD}=0.7)$. These pulses vary from 4-16 ms (mean $=9, \mathrm{SD}=2$ ), separated by intervals of $1-36 \mathrm{~ms}$ ( mean $=16, \mathrm{SD}$ =6). Dominant frequency peaks are between $4.1-4.5 \mathrm{kHz}($ mean $=4.4, \mathrm{SD}=0.2)$. On the other hand, within the series of stereotyped two-pulsed notes, the notes have regular structure, duration, interval, and number of pulses. These notes last $27-52 \mathrm{~ms}$, separated by intervals of $17-76 \mathrm{~ms}$, and are released at a rate of 542-1,101 notes per minute; notes have a slightly increase in amplitude from the first to the second pulse (see oscillogram in Fig. 4B). Pulses vary from 4-15 ms, separated by intervals of 11-40 ms, and are released at a rate of 43-74 pulses per second (Fig. 2B). Dominant (= fundamental) frequency peaks are between $3.9-5.1 \mathrm{kHz}$; the minimum frequency ranges between $1.8-4.6 \mathrm{kHz}$ and the maximum frequency ranges from $4.4-5.5 \mathrm{kHz}$. Notes have up to three harmonics; the second ranging from $6.9-9.8 \mathrm{kHz}($ mean $=8.7 ; \mathrm{SD}=0.4)$. Air temperature of recorded calls varied from 24.0 to $25.2^{\circ} \mathrm{C}$. Call quantitative traits are summarized in Table 2.

Traits that were classified as static (within-male $\mathrm{CV}<5 \%$ ) to $P$. matuta sp. nov. were note duration $($ mean $=4.2 \%, \mathrm{SD}=1.8[1.6-7.4])$, number of pulses per note $($ mean $=0 \%)$, pulse rate $($ mean $=4.2 \%$, $\mathrm{SD}=1.8[1.6-7.4]$ ), and dominant peak (mean $=0.9 \%, \mathrm{SD}=0.7[0.0-3.0])$. The other traits were classified as dynamic $(\mathrm{CV}<7.4 \%)$. Additionally, the between-male coefficient of notes per minute was equal to $9.2 \%$, this low variability among males allowed us to classify this trait as static.

We noticed a remarkable intraspecific variation in the advertisement call of $P$. matuta sp. nov., in which the three males of the population from the southern foothills of the Serra do Cipó National Park have a lower note rate (529-737 notes per minute) than those of male types (738-1101 notes per minute). It is noteworthy that the air temperatures measured during the recordings in these two localities did not overlap, $24.0-25.2^{\circ} \mathrm{C}$ at type locality, and $20.5-23.0^{\circ} \mathrm{C}$ in lowlands of the Serra do Cipó National Park. 


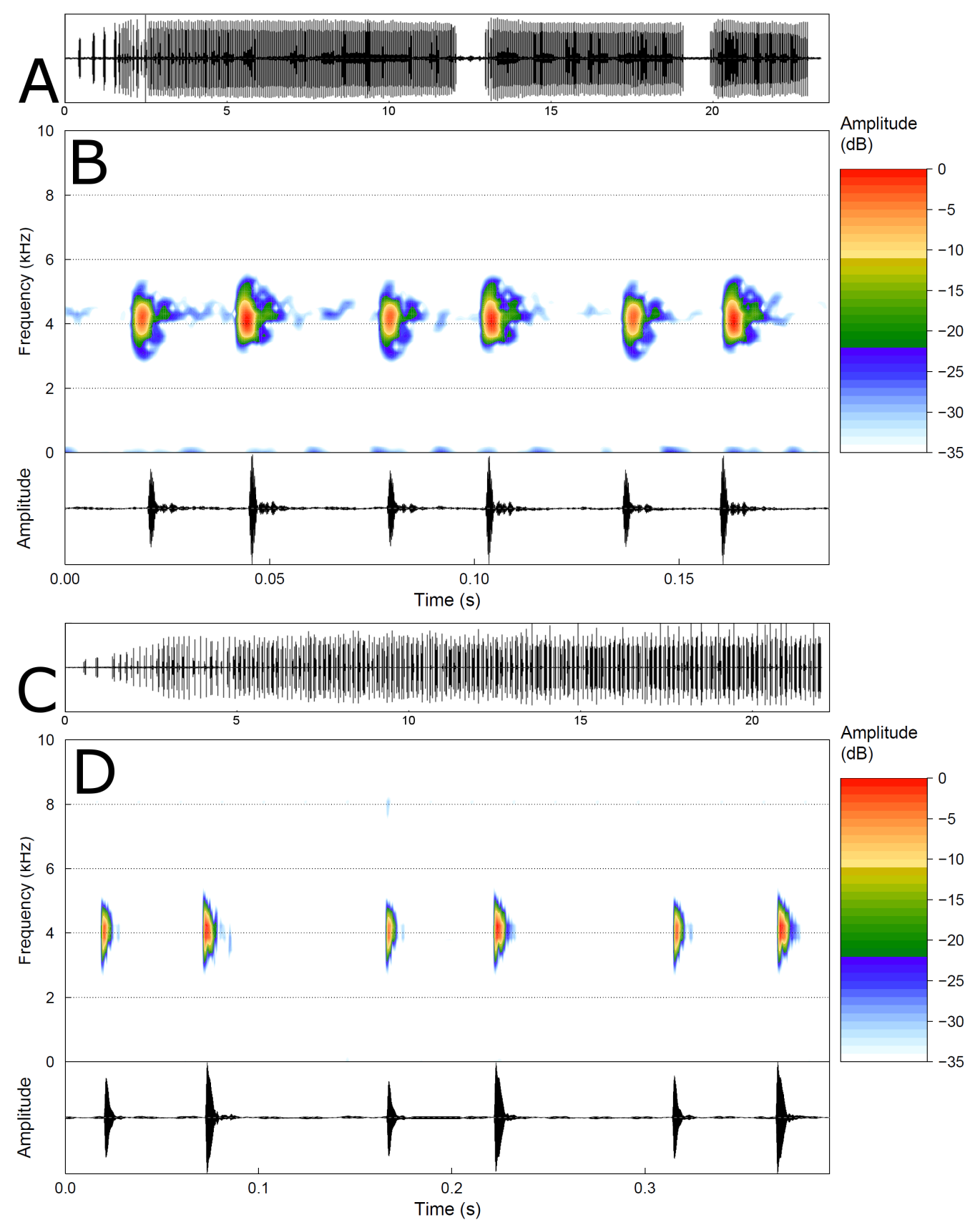

Fig. 4. A. Oscillogram of the entire advertisement call with the introductory notes and three series of two-pulsed notes of Pseudopaludicola matuta sp. nov. B. Audiospectrogram (above) and corresponding oscillogram (below) detailing three two-pulsed notes of the holotype (ZUEC 24302). The holotype was recorded on 29 Nov. 2017 at $19: 19$ h; air temperature $25.2^{\circ} \mathrm{C}$ (recording_label: Pseudop_ matutaCurveloMG10iIAH_AAGmt). C. Oscillogram of the entire advertisement call with a single series of two-pulsed notes of $P$. mineira Lobo, 1994. D. Audiospectrogram (above) and corresponding oscillogram (below) detailing three two-pulsed notes of a topotypical male (ZUEC 24330; GenBank voucher). The topotype was recorded on 4 Dec. 2017 at 19:28 h; air temperature $21.0^{\circ} \mathrm{C}$ (recording label: Psedop_mineiraSantanadoRiachoMG2aIAH_AAGm661MK2). Note the remarkable difference in the time spent emitting the same three two-pulsed notes between these two sister species, $P$. mineira spends about twice as much time than P. matuta sp. nov. 


\section{Phylogenetic inferences and mitochondrial DNA divergences}

The inferred tree topology agreed with previous phylogenetic analyses of Pseudopaludicola (VeigaMenoncello et al. 2014; Andrade et al. 2016, 2018), and was very similar between BI and ML inferences (Fig. 6). The new species was found as sister clade of P. mineira (Fig. 6). Uncorrected genetic distance between the new species and P. mineira was $3.5 \%$ (mean value) and maximum intraspecific distance was $0.1 \%$ (Table 4). No molecular data are available for P. ceratophyes, P. llanera, P. pusilla, P. hyleaustralis, P. parnaiba, P. giarettai, P. ibisoroca; however, the new species is strongly diagnosed from these species by morphology and acoustics (see further details in Differential diagnosis section).

\section{Natural history notes}

We recorded specimens of $P$. matuta sp. nov. in an area with relatively dense vegetation. In this site, there were grasses, shrub vegetation, and some spaced trees of 5-7 $\mathrm{m}$ in height, with the soil well soaked. Males of other Pseudopaludicola species usually call exposed in open areas. Curiously, two other specimens of P. matuta sp. nov. were recorded a few meters from this above-mentioned site in an open and waterlogged area, where $P$. giarettai also occurs syntopically. In both places, we observed dozens of specimens of $P$. matuta sp. nov.

However, during the fieldwork in the lowlands of the Serra do Cipó National Park, we were able to find a single small population near Lagoa da Capivara and Cipó River. During the two sampling nights, it was possible to hear only eight males, which were recorded. They were not excited and were vocalizing wellspaced from each other. This social condition may have influenced the intraspecific acoustic variation described by us. Besides that, air temperature was lower (without overlap) during the fieldwork in the lowlands of the Serra do Cipó National Park.
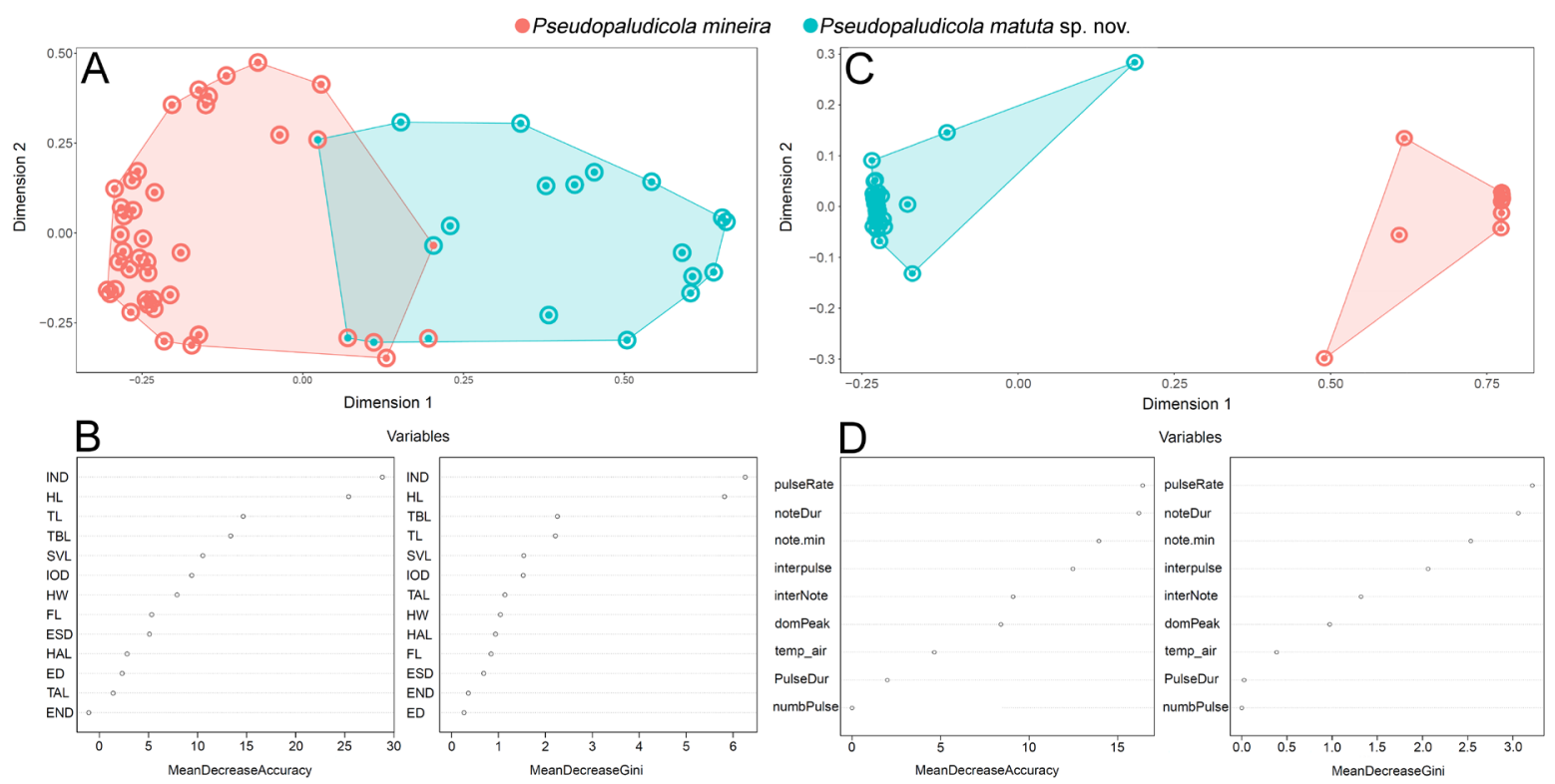

Fig. 5. First and second dimensions of the Multidimensional scaling on the proximity scores from the Random Forest analysis considering morphometric (A) and acoustic (C) traits of adult males of Pseudopaludicola matuta sp. nov. (blue dots) and P. mineira Lobo, 1994 (red dots). Dotcharts of variable importance score considering morphometric (B) and acoustic (D) traits as indicated by the Random Forest analysis. Each dot represents an adult male. 


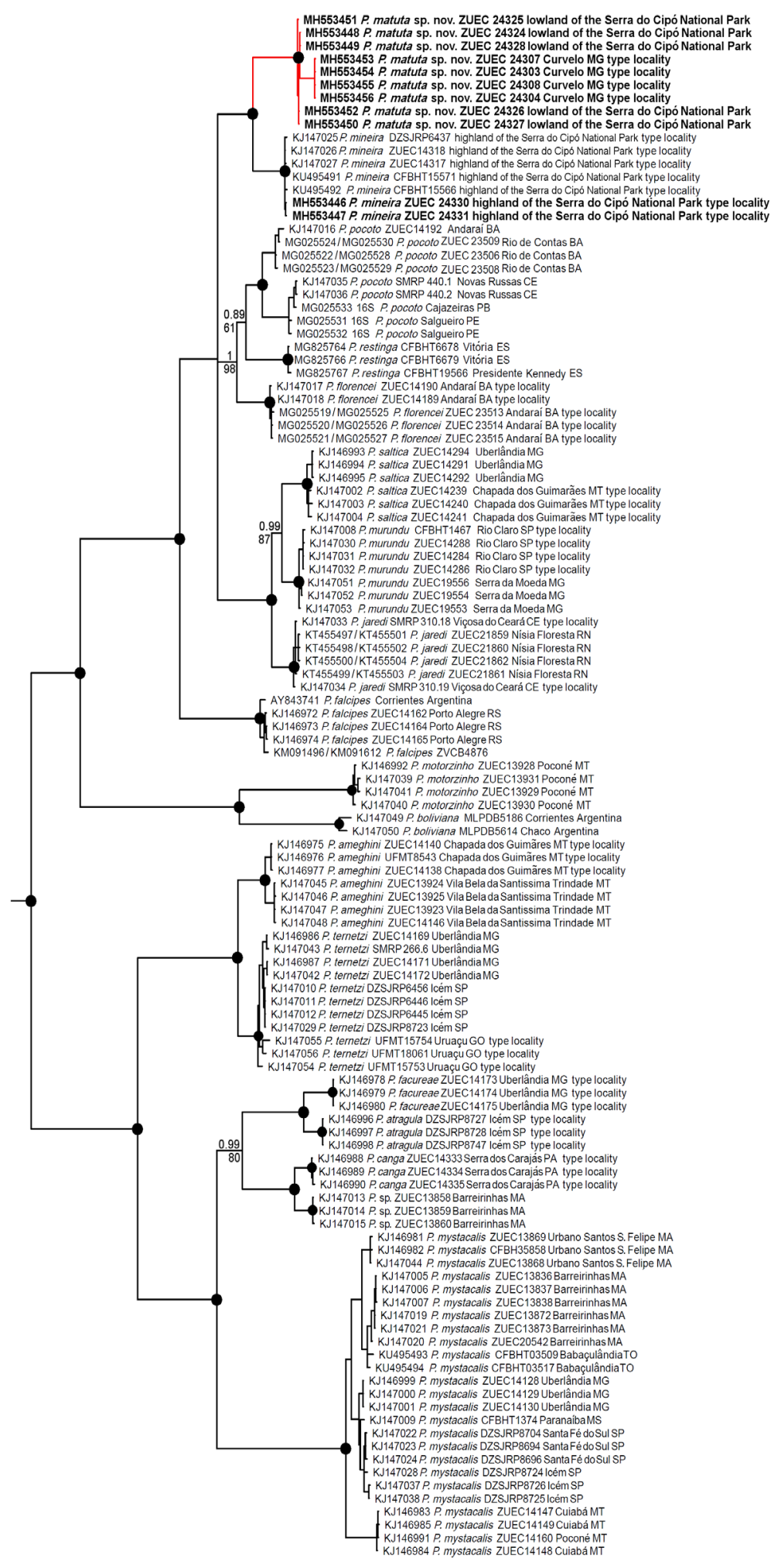

Fig. 6. 50\% majority rule consensus tree based on the $12 \mathrm{~S}$ and $16 \mathrm{~S}$ rDNA mitochondrial genes of the species of Pseudopaludicola from Bayesian inference analysis. Numbers above branches are posterior probabilities (PP) and numbers below branches are the support values from a maximum likelihood bootstrap analysis. Black dots represent $\mathrm{PP}=1$ and bootstrap $=100$; no support below species level is shown. 


\section{Distribution}

Pseudopaludicola matuta sp. nov. is known from its type locality, lowlands of the Serra do Cipó National Park (southern foothills), district of Serra do Cipó, municipality of Santana do Riacho, and in the municipality of Belo Horizonte from a report in the 1960s (Fig. 1). However, it is not possible to find this species nowadays in the municipality of Belo Horizonte (F.S.F. Leite, pers. obs.). Lobo (1994) reported the occurrence of P. mineira in the Serra do Cipó National Park (at $1264 \mathrm{~m}$ a.s.l., type locality) and in Serra do Cabral (at $1104 \mathrm{~m}$ a.s.1.), a nearby mountainous area but isolated from the main Espinhaço mountain range (Fig. 1). The altitudes we found P. matuta sp. nov. vary between 620 and $883 \mathrm{~m}$ a.s.1. In addition, in the type locality and where we collected $P$. mineira during our fieldwork are only about $14 \mathrm{~km}$ northeast from the site where we recorded P. matuta sp. nov. (797 m a.s.1., Fig. 1); however, the elevational difference between these two sites is about $460 \mathrm{~m}$. We did not find P. matuta sp. nov. during our fieldwork in the rupestrian grasslands of the Serra do Cipó National Park. Therefore, it seems that $P$. mineira is restricted to the higher rupestrian grasslands of the Serra do Cipó National Park and Serra do Cabral (Lobo 1994), whereas P. matuta sp. nov. occurs in adjacent lowland regions to the west and south of this unique Brazilian mountain range.

\section{The advertisement call and acoustic diagnosis of $P$. mineira}

Pseudopaludicola mineira also emits long advertisement calls, consisting of series of stereotyped twopulsed notes that lasts $0.4-44.3 \mathrm{~s}$, separated by intervals of $0.3-10.9 \mathrm{~s}$ (Fig. 4C). Notes last 50-114 ms separated by intervals of $42-159 \mathrm{~ms}$ and released at a rate of 282-485 notes per minute. Only six notes of one male have three non-concatenated pulses of all the analysed notes ( $\mathrm{n}=180$ notes); the other notes have two non-concatenated pulses each. Pulses vary from 4-22 ms, are separated by intervals of 5-94 ms, and are released at a rate of 17-118 pulses per second (Fig. 4D). Dominant (= fundamental) frequency peaks between $3.6-4.3 \mathrm{kHz}$, the minimum frequency ranges $2.3-3.9 \mathrm{kHz}$, and the maximum frequency ranges 4.0-4.5 kHz. Second harmonic peaks between $6.8-8.1 \mathrm{kHz}($ mean $=7.1 ; \mathrm{SD}=0.07)$. Pseudopaludicola mineira also has introductory notes with irregular structure, duration, interval, and number of pulses. Quantitative traits are summarized in Table 2. Air temperature of recorded calls varied from 16.0 to $25.5^{\circ} \mathrm{C}$.

Similarly to the new species, $P$. mineira can be distinguished from species that have non-pulsed structure or with concatenated pulses (with lack of interpulse interval): $P$. canga, $P$. giarettai, $P$. hyleaustralis, $P$. facureae, $P$. parnaiba, P. mystacalis, P. boliviana, P. ibisoroca, and P. motorzinho. Pseudopaludicola mineira distinguishes from other congeners [values within square brackets] by the following acoustic traits: P. ternetzi has higher note rate (282-485 [606-921] notes per minute), and higher number of pulses per note (2-3 [3-6]) (Andrade et al. 2017a); P. ameghini has higher number of pulses per note [3-5] (Andrade et al. 2017a); P. atragula has longer note duration (50-144 [300-700 ms], and higher number of pulses per note [9-36], and lower note rate [42-98 notes per minute] (Pansonato et al. 2014). From the three long-legged species (P. saltica, P. murundu, and P. jaredi), P. mineira is distinguished by having low variation in the number of pulses per note [2-7] (Andrade et al. 2016). Pseudopaludicola pocoto and $P$. florencei have lower note rate [100-297 notes per minute, combined values], higher dominant frequency (3.6-4.3 [4.2-6.5] kHz), and stereotyped three-pulsed notes (Magalhães et al. 2014; Andrade et al. 2017b, 2018). Pseudopaludicola mineira differs from P. falcipes by its lower dominant frequency [4.7-6.0 kHz; Andrade et al. 2018; present study]; however, the advertisement calls of these two species are quite similar in the temporal domain. We were unable to distinguish acoustically P. mineira from $P$. restinga based on data from literature (Cardozo et al. 2018). Note emission rate is one of the most informative acoustic traits to diagnose closely related species of Pseudopaludicola (e.g., Andrade et al. 2017a, 2018). In Cardoso et al. (2018) there is no measure of this feature but an estimated value from their figured sounds is around 490 notes per minute, what is within the range we observed to P. mineira. 


\section{Discussion}

The non-overlapping note rate distinguishes Pseudopaludicola matuta sp. nov. and P. mineira. This trait was classified as a static trait (sensu Gerhardt 1991) for both species, due to its low variability between-males in these species. The spectral and fine-scale temporal traits of the frog calls are usually important for species recognition, whereas variable temporal traits may be important for mate choice (Gerhardt 1991). Therefore, the species differ one from another in a temporal trait that is expected to be associated with their species recognition. In addition, note duration almost alone distinguishes P. matuta sp. nov. from P. mineira, and it was also classified as static for the new species. It is well known that environmental variables can influence the acoustic traits in anurans; however, we do not attribute the acoustic differences to air temperature differences, once the values overlapped at the time of the field recordings of the two species. However, air temperature may be a plausible explanation for the intraspecific variation in the note emission rate of $P$. matuta sp. nov. Temporal traits are more informative for species recognition than spectral traits in the genus Pseudopaludicola; especially the note rate that seems to be a reliable diagnostic character among closely related species.

The acoustic characterization of Pseudopaludicola mineira presented here is in accordance with that of Pereira \& Nascimento (2004) and provides a diagnostic support for this species in comparison with all congeners, except $P$. falcipes. Andrade et al. (2018) were unable to distinguish acoustically $P$. mineira from $P$. falcipes. Based on a larger acoustic sample of topotypes of $P$. mineira, we observed that these two species have quite similar calls in the temporal domain, without differences in any trait. However, in the spectral domain P. mineira has a lower dominant frequency $(3.8 \pm 0.2[3.6-4.3] \mathrm{kHz})$ compared to P. falcipes (5.1 \pm 0.3 [4.7-6.0] kHz; Andrade et al. 2018). However, the values of dominant frequency of $P$. mineira presented in Pereira \& Nascimento (2004) slightly overlap with those of $P$. falcipes in Andrade et al. (2018). As spectrograms are directly influenced by the settings used in acoustic analyses, as well as by the above-mentioned overlap with the data presented in Pereira \& Nascimento (2004), we prefer not to assume here that the spectral differences found between P. falcipes and P. mineira are in fact diagnostic traits.

Andrade et al. (2018) pointed out that there is only one reliable diagnostic external morphology character between $P$. mineira and P. falcipes, the absent or incomplete abdominal fold in $P$. falcipes; whereas in $P$. mineira the abdominal fold is always complete, as all other species of Pseudopaludicola. Pseudopaludicola mineira and P. falcipes are allopatric species with high genetic divergence based on mitochondrial markers (Lobo 1994; Veiga-Menoncello et al. 2014; Langone et al. 2016; Andrade et al. 2018); nuclear genes will be informative to investigate if mitochondrial introgression is involved in this case. Cardozo et al. (2018) were unable to find acoustic differences among $P$. mineira, $P$. restinga, and $P$. falcipes. According to those authors, the most closely related taxon to $P$. restinga is $P$. pocoto, which has different advertisement calls. In our phylogenetic hypothesis, we recovered $P$. restinga closely related to $P$. pocoto, but with a relatively low support. In any case, this putative relationship needs to be better established in the future.

Previous studies (Veiga-Menoncello et al. 2014; Andrade et al. 2016, 2018) were unable to completely resolve the phylogenetic relationships of $P$. mineira within the clade with $2 \mathrm{n}=22$ chromosomes (sensu Veiga-Menoncello et al. 2014). Here we recovered $P$. mineira as sister clade of $P$. matuta sp. nov. with high support, but the relationship of $P$. mineira and $P$. matuta sp. nov. within the clade $2 \mathrm{n}=22$ remains uncertain. Andrade et al. (2018) analysed acoustically one specimen of Pseudopaludicola (called by them P. mineira) from Pampulha, Belo Horizonte, Minas Gerais, recorded by W. C. A. Bokermann on 10 Feb. 1965. These authors also reported that this individual presented a considerable variation in some temporal traits of the advertisement call (e.g., pulse and note rates) when compared to the two males recorded in the Serra do Cipó National Park (type locality of P. mineira). Pseudopaludicola matuta sp. 
nov. is actually the best taxonomic identity for this specimen, from Pampulha, Belo Horizonte, based on acoustic evidence.

Pseudopaludicola mineira is classified as least-concern and suggested to be endemic to the highlands of the Serra do Cipó mountain range, occurring in shallow and temporary swamps (Leite et al. 2008). Leite et al. (2008) also reported the occurrence of P. mineira in the municipalities of Diamantina, Felício dos Santos, and São Gonçalo do Rio Preto, all in the state of Minas Gerais. However, not all specimens examined by them are from the highlands of the Serra do Cipó National Park range (F.S.F. Leite, pers. com.). Therefore, we were unable to identify whether the specimens analysed by Leite et al. (2008) are $P$. mineira or $P$. matuta sp. nov. Future phylogeographic studies will be valuable to resolve the evolutionary history of these two sister species and the role of the Espinhaço mountain range in this context.

\section{Acknowledgments}

Special thanks to the Serra do Cipó National Park for providing facilities during our research at this reserve. São Paulo Research Foundation (FAPESP) provided a doctoral fellowship to FSA (\#2015/107287) and a postdoctoral fellowship to TRC (\#2017/08489-0) and MLL (\#2017/26162-8), and a grant to LFT (\#2016/25358-3) and CFBH (\#2013/50741-7). Conselho Nacional de Desenvolvimento Científico e Tecnológico $(\mathrm{CNPq})$ and Fundação de Amparo à Pesquisa de Minas Gerais (FAPEMIG) provided financial support to AAG (\#305261/2010-0). CNPq also provided fellowships to LFT (\#300896/20166) and CFBH (\#302518/2013-4). A grant by CNPq to AAG. We thank The Cornell Lab of Ornithology (Bioacoustics Research Program) for providing free licenses to Raven Pro.

\section{References}

Andrade F.S. \& Carvalho T.R. 2013. A new species of Pseudopaludicola Miranda-Ribeiro (Leiuperinae: Leptodactylidae: Anura) from the Cerrado of southeastern Brazil. Zootaxa 3608 (5): 389-397. https://doi.org/10.11646/zootaxa.3608.5.7

Andrade F.S., Magalhães F.M., Nunes-de-Almeida C.H.L., Veiga-Menoncello A.C.P., Santana D.J., Garda A.A., Loebmann D., Recco-Pimentel S.M., Giaretta A.A. \& Toledo L.F. 2016. A new species of long-legged Pseudopaludicola from northeastern Brazil (Anura, Leptodactylidae, Leiuperinae). Salamandra 52: 107-124.

Andrade F.S., Haga I.A., Bang D.L. \& Giaretta A.A. 2017a. The differential acoustic diagnosis between two Pseudopaludicola sister species (Anura, Leptodactylidae, Leiuperinae). Zootaxa 4319 (2): 391400. https://doi.org/10.11646/Zootaxa.4319.2.12

Andrade F.S., Leite F.S.F., Carvalho T.R., Bernardes C.S. \& Giaretta A.A. 2017b. First record of Pseudopaludicola pocoto Magalhães, Loebmann, Kokubum, Haddad \& Garda, 2014 (Anura, Leptodactylidae, Leiuperinae) in Bahia state, northeastern Brazil, with further data on its advertisement call. Check List 13 (1): 2047. https://doi.org/10.15560/13.1.2047

Andrade F.S., Haga I.A., Lyra M.L., Leite F.S.F., Kwet A., Haddad C.F.B., Toledo L.F. \& Giaretta A.A. 2018. A new species of Pseudopaludicola Miranda-Ribeiro (Anura: Leptodactylidae: Leiuperinae) from eastern Brazil, with novel data on the advertisement call of Pseudopaludicola falcipes (Hensel). Zootaxa 4433 (1): 71-100. https://doi.org/10.11646/zootaxa.4433.1.4

Archer E. 2016. rfPermute: Estimate Permutation p-Values for Random Forest Importance Metrics (Computer software). R package v. 2.0.1. Available from https://CRAN.R-project.org/package=rfPermute [assessed 4 Aug. 2016].

BreimanL.2001.RandomForests.MachineLearning 45:5-32.https://doi.org/10.1023/A:1010933404324 
Bioacoustics Research Program 2014. Raven Pro: interactive sound analysis software, version 1.5. The Cornell Lab of Ornithology, Ithaca, New York. Available from http://www.birds.cornell.edu/raven [accessed 5 Feb. 2015].

Cardozo D. \& Suárez P. 2012. Osteological description of Pseudopaludicola canga with implications for the taxonomic position of this taxon. Zootaxa 3515: 75-82.

Cardozo D.E., BaldoD.,Pupin N., GaspariniJ.L.\&HaddadC.F.B.2018.Anew species of Pseudopaludicola (Anura, Leiuperinae) from Espírito Santo, Brazil. PeerJ 6: e4766. https://doi.org/10.7717/peerj.4766

Carvalho T.R. 2012. Anew species of Pseudopaludicola Miranda-Ribeiro (Leiuperinae: Leptodactylidae: Anura) from the Cerrado of southeastern Brazil with a distinctive advertisement call pattern. Zootaxa 3328: 47-54.

Carvalho T.R., Teixeira B.F.V., Martins L.B. \& Giaretta A.A. 2015a. Intraspecific variation and new distributional records for Pseudopaludicola species (Anura, Leptodactylidae, Leiuperinae) with trilled advertisement call pattern: diagnostic characters revisited and taxonomic implications. North-Western Journal of Zoology 11: 262-273.

Carvalho T.R., Borges-Martins M., Teixeira B.F.V., Godinho L.B. \& Giaretta A.A. 2015b. Intraspecific variation in acoustic traits and body size, and new distributional records for Pseudopaludicola giarettai Carvalho, 2012 (Anura, Leptodactylidae, Leiuperinae): implications for its congeneric diagnosis. Papéis Avulsos de Zoologia 55: 245-254. https://doi.org/10.1590/0031-1049.2015.55.17

Duré M.I., Schaefer E.F., Hamann M.I. \& Kehr A.I. 2004. Consideraciones ecológicas sobre la dieta, la reproducción y el parasitismo de Pseudopaludicola boliviana (Anura, Leptodactylidae) de Corrientes, Argentina. Phyllomedusa 3: 121-131. https://doi.org/10.11606/issn.2316-9079.v3i2p121-131

Feller A.E. \& Hedges S.B. 1998. Molecular evidence for the early history of living amphibians. Molecular Phylogenetics and Evolution 9 (3): 509-516. https://doi.org/10.1006/mpev.1998.0500

Frost D.R. 2018. Amphibian Species of the World: an Online Reference. Version 6.0. New York (NY), USA: American Museum of Natural History. Available from http://research.amnh.org/herpetology/amphibia/index.html [accessed 20 Jun. 2018]

Gerhardt H.C. 1991. Female mate choice in treefrogs: static and dynamic acoustic criteria. Animal Behaviour 42: 615-635. https://doi.org/10.1016/S0003-3472(05)80245-3

Giaretta A.A. \& Kokubum M.N.C. 2003. A new species of Pseudopaludicola (Anura, Leptodactylidae) from northern Brazil. Zootaxa 383: 1-8. https://doi.org/10.11646/zootaxa.383.1.1

Giaretta A.A. \& Facure K.G. 2009. Habitat, egg-laying behaviour, eggs and tadpoles of four sympatric species of Pseudopaludicola (Anura, Leiuperidae). Journal of Natural History 43: 995-1009. https://doi.org/10.1080/00222930802702456

Guindon S., Dufayard J.F., Lefort V., Anisimova M., Hordijk W. \& Gascuel O. 2010. New Algorithms and Methods to Estimate Maximum-Likelihood Phylogenies: Assessing the Performance of PhyML 3.0. Systematic Biology 59 (3): 307-21. https://doi.org/10.1093/sysbio/syq010

Hedges S.B. 1994. Molecular evidence for the origin of birds. Proceedings of the National Academy of Sciences of the United States of America 91 (7): 2621-2624. https://doi.org/10.1073/pnas.91.7.2621

Heyer W.R., Rand A.S., Cruz C.A.G., Peixoto O.L. \& Nelson C.E. 1990. Frogs of Boracéia. Arquivos de Zoologia 31: 235-410. https://doi.org/10.11606/issn.2176-7793.v31i4p231-410

Hothorn T., Hornik K., Wiel M.A. van de \& Zeileis A. 2008. Implementing a class of permutation tests: the coin package. Journal of Statistical Software 28 (8): 1-23. https://doi.org/10.18637/jss.v028.i08 
Katoh K. \& Standley D.M. 2013. MAFFT multiple sequence alignment software version 7: improvements in performance and usability. Molecular Biology and Evolution 30 (4): 772-780. https://doi.org/10.1093/molbev/mst010

Kessing B., Croom H., Martin A., McIntosh C., MacMillan W.O. \& Palumbi S. 1989. The simple fool's guide to PCR. Version 1.0. Special Publication. Department of Zoology, University of Hawaii, Honolulu.

Köhler J., Jansen M., Rodríguez A., Kok P.J.R., Toledo L.F., Emmrich M., Glaw F., Haddad C.F.B., Rödel M.O. \& Vences M. 2017. The use of bioacoustics in anuran taxonomy: theory, terminology, methods and recommendations for best practice. Zootaxa 4251: 1-124. https://doi.org/10.11646/zootaxa.4251.1.1

Lanfear R., Calcott B., Ho S.Y.W. \& Guindon S. 2012. PartitionFinder: combined selection of partitioning schemes and substitution models for phylogenetic analyzes. Molecular Biology and Evolution 29: 16951701. https://doi.org/10.1093/molbev/mss020

Langone J.A., Camargo A. \& de Sá R.O. 2016. High genetic diversity but low population structure in the frog Pseudopaludicola falcipes (Hensel, 1867) (Amphibia, Anura) from the Pampas of South America. Molecular Phylogenetics and Evolution 95: 137-151. https://doi.org/10.1016/j.ympev.2015.11.012

Lefort V., Longueville J.E \& Gascuel O. 2017. SMS: Smart Model Selection in PhyML. Molecular Biology and Evolution 34 (9): 2422-2424. https://doi.org/10.1093/molbev/msx149

Leite F.S.F., Juncá F.A. \& Eterovick P.C. 2008. Status do conhecimento, endemismo e conservação de anfíbios anuros da Cadeia do Espinhaço, Brasil. In: da Silva J.M.C. (ed.) Megadiversidade: Cadeia do Espinhaço: avaliação do conhecimento cientifico e prioridades de conservação: 158-176. Conservação Internacional Brasil, Belo Horizonte.

Liaw A. \& Wiener M. 2002. Classification and regression by randomForest. $R$ News 2: 18-22.

Lobo F. 1994. Descripción de una nueva especie de Pseudopaludicola (Anura: Leptodactylidae), redescripción de P. falcipes (Hensel, 1867) y P. saltica (Cope, 1887). Cuadernos de Herpetología 8: $177-199$.

Lobo F. 1995. Análisis filogenético del género Pseudopaludicola (Anura: Leptodactylidae). Cuadernos de Herpetologia 9: 21-43.

Lynch J.D. 1989. A review of leptodactylid frogs of the genus Pseudopaludicola in northern South America. Copeia 1989 (3): 577-588. https://doi.org/10.2307/1445483

Lyra M.L., Haddad C.F.B. \& Azeredo-Espin A.M.L. 2017. Meeting the challenge of DNA barcoding Neotropical amphibians: polymerase chain reaction optimization and new COI primers. Molecular Ecology Resources 17 (5): 966-980. https://doi.org/10.1111/1755-0998.12648

Magalhães F.M., Loebmann D., Kokubum M.N.C., Haddad C.F.B. \& Garda A.A. 2014. A new species of Pseudopaludicola (Anura: Leptodactylidae: Leiuperinae) from northeastern Brazil. Herpetologica 70: 77-88. https://doi.org/10.1655/HERPETOLOGICA-D-13-00054

Maniatis T., Fritsch E.F. \& Sambrook J. 1982. Molecular cloning: a laboratory manual. Cold Spring Harbor Laboratory, New York.

Miller M.A., Pfeiffer W. \& Schwartz T. 2010. Creating the CIPRES Science Gateway for inference of large phylogenetic trees. Proceedings of the Gateway Computing Environments Workshop (GCE) 2010: 1-8. https://doi.org/10.1109/GCE.2010.5676129

Pansonato A., Morais D.H., Ávila R.W., Kawashita-Ribeiro R.A., Strüssmann C. \& Martins I.A. 2012. A new species of Pseudopaludicola Miranda-Ribeiro, 1926 (Anura: Leiuperidae) from the state of Mato Grosso, Brazil, with comments on the geographic distribution of Pseudopaludicola canga Giaretta \& Kokubum, 2003. Zootaxa 3523: 49-58. 
Pansonato A., Strüssmann C., Mudrek J.R. \& Martins I.A. 2013. Morphometric and bioacoustic data on three species of Pseudopaludicola Miranda-Ribeiro, 1926 (Anura: Leptodactylidae: Leiuperinae) described from Chapada dos Guimarães, Mato Grosso, Brazil, with the revalidation of Pseudopaludicola ameghini (Cope, 1887). Zootaxa 3620 (1): 147-162. https://doi.org/10.11646/zootaxa.3620.1.7

Pansonato A., Mudrek J.R., Veiga-Menoncello A.C.P., Rossa-Feres D.C., Martins I.A. \& Strüssmann C. 2014. A new species of Pseudopaludicola Miranda-Ribeiro, 1926 (Anura: Leptodactylidae: Leiuperinae) from northwestern state of São Paulo, Brazil. Zootaxa 3861: 249-264. https://doi.org/10.11646/zootaxa.3861.3.3

Pansonato A., Veiga-Menoncello A.C.P., Mudrek J.R., Jansen M., Recco-Pimentel S.M., Martins I.A. \& Strüssmann C. 2016. Two new species of Pseudopaludicola (Anura: Leptodactylidae: Leiuperinae) from eastern Bolivia and western Brazil. Herpetologica 72: 235-255. https://doi.org/10.1655/Herpetologica-D-14-00047.1

Pereira E.G. \& Nascimento L.B. 2004. Descrição da vocalização e do girino de Pseudopaludicola mineira Lobo, 1994, com notas sobre a morfologia de adultos (Amphibia, Anura, Leptodactylidae). Arquivos do Museu Nacional 62: 233-240.

Queiroz K. de 1998. The general lineage concept of species, species criteria, and the process of speciation and terminological recommendations. In: Howard D.J. \& Berlocher, S.H. (eds) Endless forms: species and speciation: 57-75. Oxford University Press, Oxford.

Queiroz K. de 2007. Species concepts and species delimitation. Systematic Biology 56 (6): 879-886. https://doi.org/10.1080/10635150701701083

R Core Team 2017. R: A language and environment for statistical computing. R Foundation for Statistical Computing, Vienna, Austria. Version 3.1.2. Available from http://www.R-project.org/ [accessed $1 \mathrm{Jul}$. 2017].

Roberto I.J., Cardozo D.\& Ávila R.W.2013. Anew species of Pseudopaludicola (Anura, Leiuperidae) from western Piauí State, Northeast Brazil. Zootaxa 3636:348-360. https://doi.org/10.11646/zootaxa.3636.2.6

Ronquist F., Teslenko M., Van Der Mark P., Ayres D.L., Darling A., Höhna S., Larget B., Liu L., Suchard M.A. \& Huelsenbeck J.P. 2012. Mrbayes 3.2: Efficient Bayesian phylogenetic inference and model choice across a large model space. Systematic Biology 61 (3): 539-542. https://doi.org/10.1093/sysbio/sys029

Sueur J., Aubin T. \& Simonis C. 2008. Seewave, a free modular tool for sound analysis and synthesis. Bioacoustics 18: 213-226. https://doi.org/10.1080/09524622.2008.9753600

Tamura K., Stecher G., Perterson D., Filipski A. \& Kumar S. 2013. MEGA6: Molecular Evolutionary Genetics Analysis Version 6.0. Molecular Biology and Evolution 30 (12): 2725-2729. https://doi.org/10.1093/molbev/mst197

Toledo L.F. 2010. Description of a new species of Pseudopaludicola Miranda-Ribeiro, 1926 from the state of São Paulo, Southeastern Brazil (Anura, Leiuperidae). Zootaxa 2681: 47-56.

Toledo L.F., Siqueira S., Duarte T.C., Veiga-Menoncello A.C.P., Recco-Pimentel S.M. \& Haddad C.F.B. 2010. Description of a new species of Pseudopaludicola Miranda-Ribeiro, 1926 from the State of São Paulo, Southeastern Brazil (Anura, Leiuperidae). Zootaxa 2496: 38-48.

Veiga-Menoncello A.C.P., Lourenço L.B., Strüssmann C., Rossa-Feres D.C., Andrade G.V., Giaretta A.A. \& Recco-Pimentel S.M. 2014. A phylogenetic analysis of Pseudopaludicola (Anura) providing evidence of progressive chromosome reduction. Zoologica Scripta 43:261-272. https://doi.org/10.1111/zsc.12048

Walker M., Lyra M.L. \& Haddad C.F.B. 2018. Phylogenetic relationships and cryptic species diversity in the Brazilian Egg-Brooding tree frog, genus Fritziana Mello-Leitão 1937 (Anura: Hemiphractidae). Molecular Phylogenetic and Evolution 123: 59-72. https://doi.org/10.1016/j.ympev.2018.02.012 
Watters J.L., Cummings S.T., Flanagan R.L. \& Siler C.D. 2016. Review of morphometric measurements used in anuran species descriptions and recommendations for a standardized approach. Zootaxa 4072 (4): 477-495. http://doi.org/10.11646/zootaxa.4072.4.6

Manuscript received: 2 July 2018

Manuscript accepted: 4 September 2018

Published on: 29 November 2018

Topic editor: Koen Martens

Desk editor: Natacha Beau

Printed versions of all papers are also deposited in the libraries of the institutes that are members of the EJT consortium: Muséum national d'Histoire naturelle, Paris, France; Meise Botanic Garden, Belgium; Royal Museum for Central Africa, Tervuren, Belgium; Natural History Museum, London, United Kingdom; Royal Belgian Institute of Natural Sciences, Brussels, Belgium; Natural History Museum of Denmark, Copenhagen, Denmark; Naturalis Biodiversity Center, Leiden, the Netherlands; Museo Nacional de Ciencias Naturales-CSIC, Madrid, Spain; Real Jardín Botánico de Madrid CSIC, Spain; Zoological Research Museum Alexander Koenig, Bonn, Germany.

\section{Appendix I: Examined specimens}

\section{Pseudopaludicola matuta sp. nov.}

BRAZIL: Minas Gerais, Curvelo (type locality): AAG-UFU 0308, 0386-7, and ZUEC 24302-12; Santana do Riacho (lowlands of the Serra do Cipó National Park): ZUEC 24324-9.

\section{Pseudopaludicola mineira}

BRAZIL: Minas Gerais, Santana do Riacho (highlands of the Serra do Cipó National Park - type locality): ZUEC 1570, 1572-89, 1591, 24330-31; MZUSP 56858-61 (type series), MZUSP 57719-24

\section{Pseudopaludicola florencei}

BRAZIL: Bahia, Andaraí, urban area: ZUEC 23512-30; Área de Proteção Ambiental MarimbusIraquara: UFMG 4310-6; Mutuípe: CFBH 29652; Minas Gerais, Nanuque: CFBH 33235.

\section{Pseudopaludicola pocoto}

BRAZIL: Ceará, Novas Russas: CFBH 20285-7; Santa Quitéria (type locality): CFBH 26842-7; Bahia, Rio de Contas: ZUEC 25506-10, UFMG 5902-11.

\section{Pseudopaludicola giarettai}

BRAZIL: Minas Gerais, Curvelo: AAG-UFU 0309-17. 


\section{Pseudopaludicola falcipes}

BRAZIL: Rio Grande do Sul, Eldorado do Sul: ZUEC 11468; Novo Hamburgo: ZUEC 4876; Porto Alegre: ZUEC 10387-8, 13999-4000, 14002-3, 14005-6, 14008-9, 14016-7, 14022, 14162-6, 14168; Santana do Livramento: ZUEC 10355-6; Viamão: ZUEC 5297-9.

\section{Pseudopaludicola ameghini}

BRAZIL: Mato Grosso, Chapada dos Guimarães: ZUEC 14138-9, 14141-5.

\section{Pseudopaludicola boliviana}

ARGENTINA: Chaco, Departamento San Fernando, Antequera: MNRJ 75298; Corrientes, Departamento General Paz, Itaibaté: MNRJ 75299; Santa Fé, Departamento General Obligado: MNRJ 75300; Formosa, Departamento Formosa, Três Marias: MNRJ 75301; Riacho Formosa: MNRJ 75303; Tatoné: MNRJ 75304-8; Formosa, Departamento Pilagas, Virasol: MNRJ 75309-12; Departamento Patiño, Colônia Salvación: MNRJ 75322.

\section{Pseudopaludicola canga}

BRAZIL: Pará, Marabá, Serra dos Carajás: ZUEC 9990, 10034, 14370, 14372-4, 14378.

\section{Pseudopaludicola facureae}

BRAZIL: Minas Gerais, Uberlândia: AAG-UFU 0853-55, ZUEC 13651-2, 14215, 14218-9, 14221, 14224.

\section{Pseudopaludicola jaredi}

BRAZIL: Ceará, Viçosa do Ceará: CFBH 32609, 32614, 32617-25, ZUEC 20477-84; Nísia Floresta: ZUEC 21858-72.

\section{Pseudopaludicola murundu}

BRAZIL: São Paulo, Águas de Santa Bárbara: ZUEC 20507-8; Rio Claro: AAG-UFU 5125-6, CFBH 8235-42, ZUEC 14284-90; Minas Gerais, Brumadinho: ZUEC 16396-8, 16442-3, 19549, 19551, 19555, 19557-8, 19560; Santana do Riacho: ZUEC 2323; São João del Rei: ZUEC 16447-52; 16455-6.

\section{Pseudopaludicola mystacalis}

BRAZIL: Goiás, Itapirapuã: ZUEC 10222; Mato Grosso, Cáceres: ZUEC 10286; Chapada dos Guimarães: ZUEC 5115, 5117, 5119, 5121, 10685; Mato Grosso do Sul, Três Lagoas: ZUEC 16720, 16949; Tocantins, Formoso do Araguaia: ZUEC 10154.

\section{Pseudopaludicola saltica}

BRAZIL: Mato Grosso, Chapada dos Guimarães: ZUEC 14228, 14230-3, 14235, 14239-40, 14244, 14247, 14272, 5134-6, 5854-5; Minas Gerais, Uberlândia: AAG-UFU 2308, 2630, 4598, 4631, 4735, $4707-11$.

\section{Pseudopaludicola ternetzi}

BRAZIL: Goiás, Uruaçu: MNRJ 445-7, 5460-2, 5442; Minas Gerais, Uberlândia: ZUEC 14036-9, 14170-1; Tocantins, Formoso do Araguaia: ZUEC 10140-3, 10145, 10147, 10150, and 10153. 